\title{
The Ediacaran Period: a new addition to the geologic time scale
}

\author{
ANDREW H. KNOLL, MALCOLM R. WALTER, GUY M. NARBONNE AND NICHOLAS CHRISTIE-BLICK
}

LETHAIA

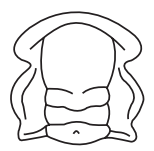

Knoll, A.H., Walter, M.R., Narbonne, G.M. \& Christie-Blick, N. 200603 31: The Ediacaran Period: a new addition to the geologic time scale. Lethaia, Vol. 39, pp. 13-30. Oslo. ISSN 0024-1164.

\begin{abstract}
The International Union of Geological Sciences has approved a new addition to the geologic time scale: the Ediacaran Period. The Ediacaran is the first Proterozoic period to be recognized on the basis of chronostratigraphic criteria and the first internationally ratified, chronostratigraphically defined period of any age to be introduced in more than a century. In accordance with procedures established by the International Commission on Stratigraphy, the base of the Ediacaran Period is defined by a Global Stratotype Section and Point (GSSP) placed at the base of the Nuccaleena Formation cap carbonate directly above glacial diamictites and associated facies at Enorama Creek in the Flinders Ranges of South Australia. Its top is defined by the initial GSSP of the Cambrian Period. The new Ediacaran Period encompasses a distinctive interval of Earth history that is bounded both above and below by equally distinctive intervals. Both chemostratigraphic and biostratigraphic data indicate that the subdivision of the period into two or more series is feasible, and this should be a primary objective of continuing work by the Ediacaran Subcommission of the ICS. $\square$ Ediacaran, Geologic time scale, global stratotype section and point, Proterozoic.
\end{abstract}

Andrew H. Knoll [aknoll@oeb.harvard.edu], Department of Organismic and Evolutionary Biology, Harvard University, Cambridge, MA 02138, USA; Malcolm R. Walter [malcolm.walter@mq.edu.au], Australian Centre for Astrobiology, Department of Earth and Planetary Sciences, Macquarie University, Sydney NSW 2109, Australia; Guy M. Narbonne [narbonne@geol.queensu.ca], Department of Geological Sciences and Geological Engineering, Queen's University, Kingston, Ontario K7L 3N6, Canada; Nicholas Christie-Blick [ncb@ldeo.columbia.edu], Department of Earth and Environmental Sciences and LamontDoherty Earth Observatory of Columbia University, Palisades, NY 10964, USA; 4th June 2004, revised 18th July 2005.
In The Origin of Species, Charles Darwin (1859) explained the apparently sudden appearance of complex animals in Cambrian rocks as the stratigraphic product of massive record failure. Charles Doolittle Walcott (1914) later formalized this view, defining the Lipalian Interval as the unrecorded period of time reflected in the unconformity between lowermost Cambrian strata and the (commonly deformed) rocks that lay beneath them. Although the Lipalian concept enjoyed early popularity, stratigraphers working in some parts of the world already knew that, regionally, Cambrian successions lay more or less conformably atop well preserved sedimentary successions, some of them thousands of meters thick. Regional characterizations (and names) of immediately sub-Cambrian strata proliferated. By 1960, however, Termier and Termier could speak in terms of a global 'Ediacarien' interval that not only recorded immediately pre-Cambrian time, but contained simple animal fossils, as envisioned by Darwin.

As early as 1922, A.W. Grabau proposed the term Sinian for a discrete system of sedimentary rocks underlying Lower Cambrian strata in the Yangtze Gorges region of China. In pioneering chronostratigraphic research, Boris Sokolov (1952) subsequently articulated the concept of a (partially correlative) Vendian System, based on a widespread interval of sub-Cambrian siliciclastic rocks on the Russian Platform and in the Ural Mountains. Initially restricted to rocks deposited during and after the Redkino transgression, Sokolov later expanded the Vendian System to include the Laplandian glacial level, best known from Uralian exposures (summarized in Sokolov 1984, 1997). By the 1960s, both continental glaciation (Harland \& Rudwick 1964) and Ediacaran fossils (Glaessner 1966) were known to occur globally, and both loomed large in attempts to understand regional and global correlations. With these in mind, Harland \& Herod (1975) and Harland et al. (1990) proposed the Ediacaran as an epoch within the Vendian Period. Cloud \& Glaessner (1982), in turn, suggested that the Ediacarian (note spelling) be recognized as a period, its beginning marked by the base of the cap carbonate that overlies Marinoan diamictites in South Australia. Jenkins (1981) had earlier proposed an etymologically similar but conceptually distinct Ediacaran Period, its base placed somewhat higher, near the first appearance of the Ediacara Biota in South Australian sections. (In this paper, we use the term Ediacara Biota in reference to the distinctive 
macroscopic fossils preserved mostly as casts and molds in rocks of Ediacaran age.)

In 1991, in a radical departure from Phanerozoic convention, the International Commission on Stratigraphy ratified a series of Proterozoic periods based strictly on geochronometric subdivision of the eon (Plumb 1991). Three eras and eight periods were defined, but the terminal Proterozoic period - the time interval immediately prior to the Cambrian - was left for later definition and characterization because in this youngest Proterozoic interval, at least, it might be possible to combine geochronological and geochronometric criteria, thereby providing a conceptual join between Proterozoic and Phanerozoic time scales (e.g. Knoll 2000). After more than a decade of research and debate (see appendix), the ICS Subcommission on the Terminal Proterozoic Period voted to define the initial GSSP for the terminal Proterozoic period, now named the Ediacaran Period, at the stratigraphic level originally proposed by Cloud and Glaessner. This proposal was approved by the International Commission on Stratigraphy and ratified by the International Union of Geological Sciences in late March 2004.

The new Ediacaran Period reflects the Subcommission's identification of an initial GSSP that can be correlated with confidence throughout the world. But it does more than that. The Ediacaran Period encompasses a coherent (and remarkable) interval of Earth history. The period begins with the termination of the last great global glaciation of the Neoproterozoic Era, an extraordinary interval when continental glaciers reached sea level in tropical latitudes. Even the name of the preceding period, the Cryogenian, reflects the centrality of glaciation to the interval that bounds the Ediacaran from below. The end of the period is marked by the initial GSSP of the Cambrian Period, again marking the beginning of a biologically distinct world characterized by diverse skeletal fossils of bilaterian animals. The beginning and the end of the Ediacaran Period are also marked by strong negative excursions in the carbon isotopic record, unusual biogeochemical events recognized globally in both carbonate rocks and sedimentary organic matter. And in between, we find the unique biological signature that gives the period its name Ediacara macrofossils known globally from terminal Proterozoic rocks (and either absent or of little ecological importance both earlier and later). As generations of stratigraphers have recognized, the Ediacaran is a distinctive period of time that is bounded above and below by equally distinctive intervals - the Ediacaran, thus, deserves formal recognition as a period, and it is fitting that its name reflects the central biological feature of the interval.

\section{Issues and opportunities}

In recent years, the Phanerozoic time scale has been reformulated in terms of Global Standard Stratotypesections and Points that precisely define the beginnings of periods or other time intervals (e.g. Chlupác \& Vacek 2003). Accepted convention for boundary definition stresses the first appearances of animal fossils and frowns on GSSP placement at unconformities, where biostratigraphic ranges may be truncated.

Despite the preference for fossils in GSSP placement, it is widely recognized that carbon (and, less completely realized, sulfur and strontium) isotopic chemostratigraphy offers a complementary tool for correlation, and even boundary definition, especially at the three great era bounding events of Phanerozoic history: the beginning of the Cambrian Period, the Permian-Triassic mass extinction, and mass extinction at the CretaceousTertiary boundary. During these intervals of Earthaltering environmental perturbation, chemostratigraphy likely permits interbasinal correlations at least as precise as those offered by invertebrate fossils.

The tools for Proterozoic correlation also include fossils and chemostratigraphy (e.g. Knoll \& Walter 1992). Ediacaran animal fossils and acritarchs both provide excellent means of recognizing and characterizing terminal Proterozoic rocks (Fig. 1). As bases for GSSP placement, however, their usefulness is limited known fossil occurrences are simply too sparse to support correlations that are accurate to within the desired resolution of a million years or less.

GSSP definition for the terminal Proterozoic period (or any earlier period defined geochronologically) will necessarily rely on the physical and chemical records of major events in Earth history. Fortunately, Neoproterozoic time offers several events of the required magnitude - the great ice ages that wracked the later Neoproterozoic world. Because these events were global in impact, and because they are associated with carbon isotopic excursions larger than any recorded in Phanerozoic rocks, the glaciations offer what are undoubtedly our best opportunities for the subdivision of Neoproterozoic time. Prominent unconformities are present at the base of many Neoproterozoic glacial units, particularly around the margins of sedimentary basins, in platform interiors, and at locations where ice was grounded. Generally more subtle unconformities are observed locally also at the tops of these units, perhaps as a result of isostatic rebound following retreat of the ice. For these geochemical and stratigraphic reasons, a GSSP placement that reflects deglaciation maximizes confidence in correlation and minimizes the uncertainties commonly associated with unconformities. 

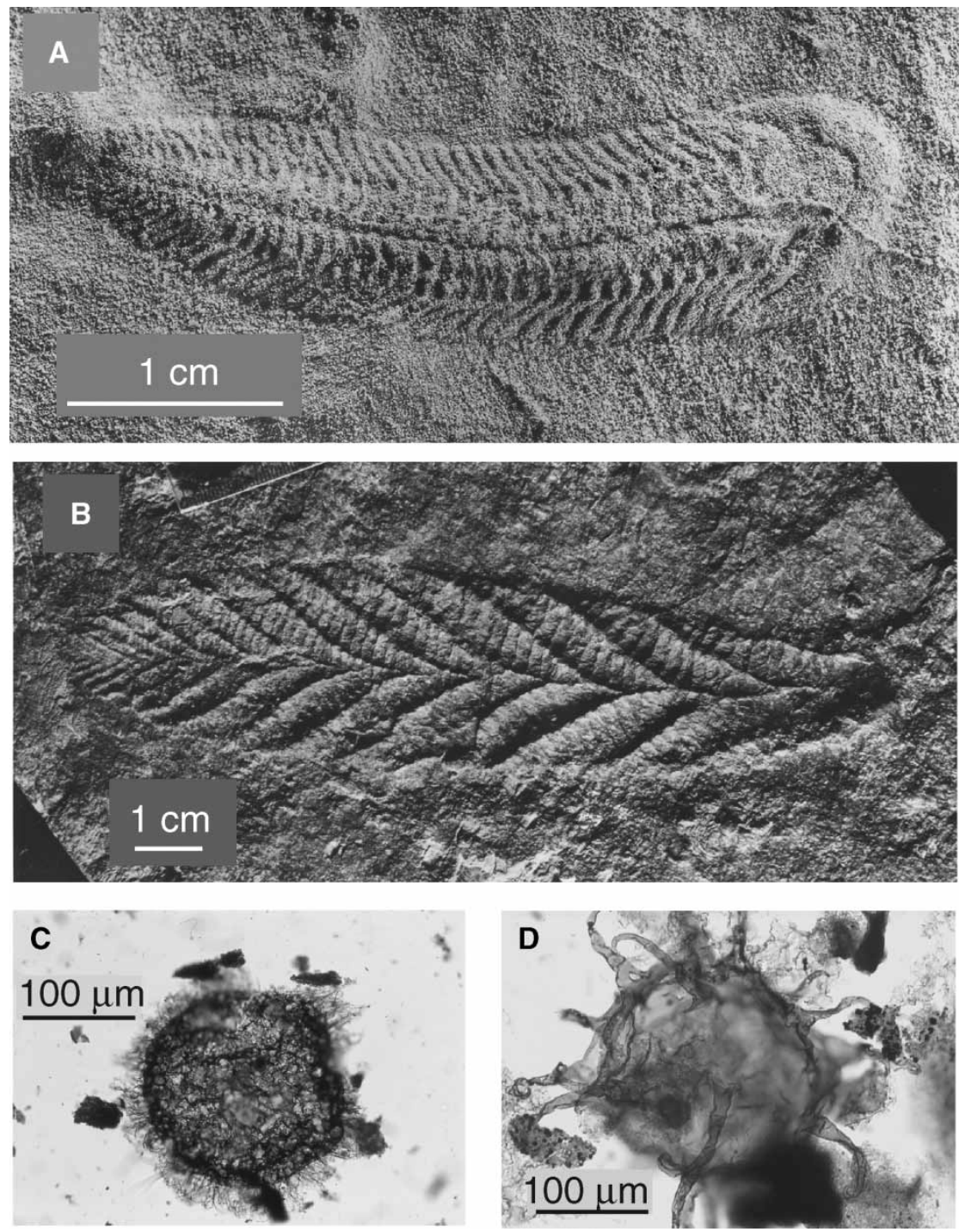

Fig. 1. Key fossil groups of the Ediacaran Period. A, B. Ediacara macrofossils; C, D. acritarchs. $\square$ A. Spriggina floundersi Glaessner, 1958, photo of latex cast, from lower cycle of Ediacara Member, Rawnsley Quartzite, Pound Subgroup, northern Ediacara Range, South Australia. $\square$ B. Charnia masoni Ford, 1958, holotype, from Hallgate Member of Bradgate Formation, Maplewell Group, Charnian Supergroup, north quarry on the golf course at Woodhouse Eaves, Charnwood Forest, Leicestershire, England. $\square$ C. Appendisphaera barbata Grey 2005, Pertatataka Formation, Amadeus Basin, Northern Territory, Australia. $\square$ D. Tanarium conoideum Kolosova, 1991, emend. Moczydlowska, Vidal \& Rudavskaya 1993, Tanana Formation, Officer Basin, South Australia. Photographs: A, B by R. J. F. Jenkins, C, D by K. Grey, reproduced with permission.

Texturally unusual carbonate beds (cap carbonates; Fig. 2) and extraordinary C-isotopic excursions (Fig. 3) provide universal signatures of ice age termination that are not only unambiguously recognizable, but also stratigraphic reflections of relatively rapid, and according to some, even catastrophic deglaciation (Kennedy 1996; Hoffman \& Schrag 2002; Halverson et al. 2005). Thus, temporal uncertainties in the correlation of isotopic signatures of cap carbonates above Marinoan glacial deposits are lower than those for any other known Proterozoic events. Indeed, it is likely that they allow time resolution of less than one million years, similar to or better than the temporal resolution that any reasonable understanding of biology permits us to place on the fossil-based GSSPs of Palaeozoic periods.

The number and correlation of Neoproterozoic glacial intervals has been a subject of debate (e.g. Kaufman et al. 1997; Kennedy et al. 1998), but recent progress on radiometric dating and chemostratigraphy now suggests two truly global ice ages. Uranium-lead zircon dates of $723+16 /-10 \mathrm{Ma}$ (Brasier et al. 2000), $709 \pm 5 \mathrm{Ma}$ (Fanning \& Link 2003) and $684 \pm 4 \mathrm{Ma}$ (Lund et al. 2003) on volcaniclastic sandstone, an ash bed and a rhyolite flow within glacial units, respectively, and $667 \pm$ $5 \mathrm{Ma}$ from an ash bed immediately above glacial rocks (Fanning \& Link 2003) constrain the time placement if not the full duration of Sturtian glaciation. Constraints 

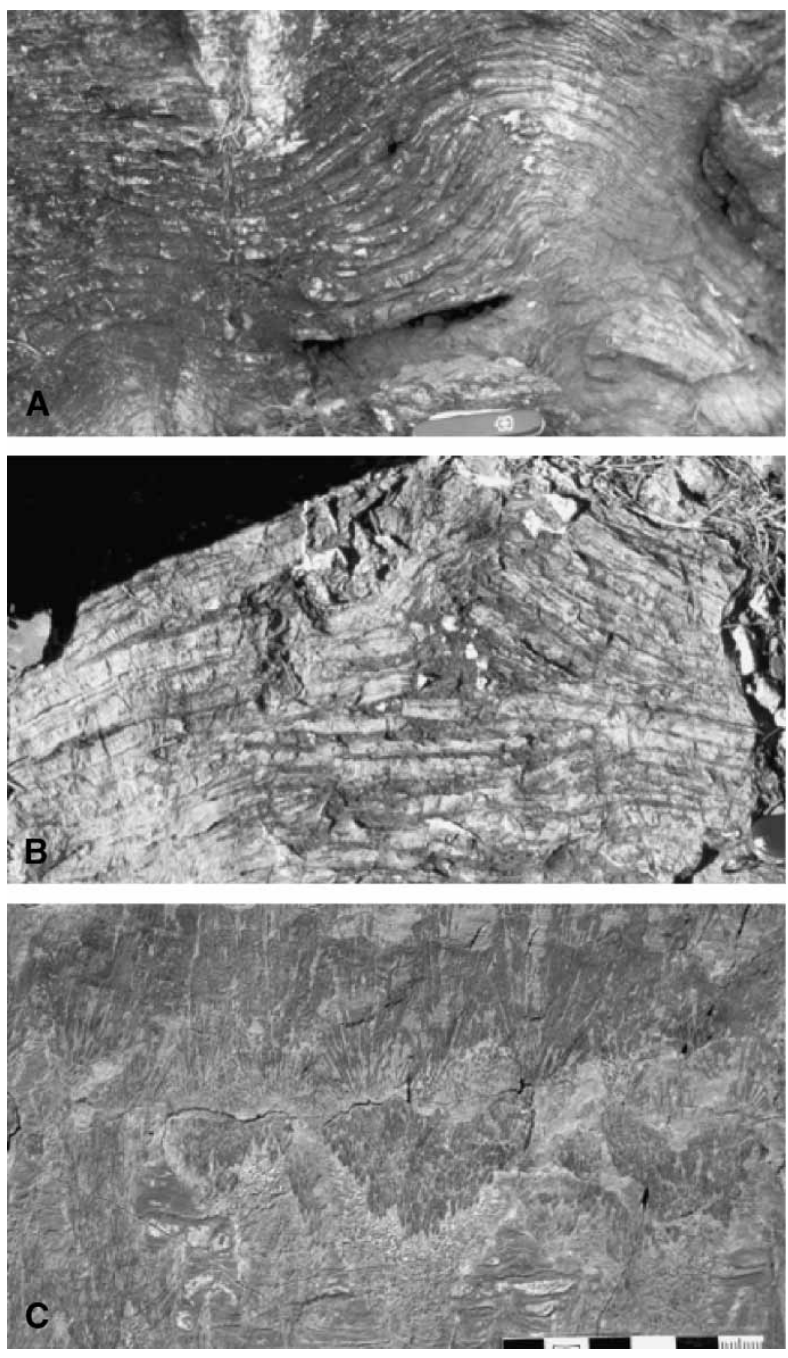

Fig. 2. Distinctive sedimentary features found in cap carbonates above Marinoan glaciogenic rocks. $\square$ A. A domal form of thin dolomite beds lined by marine cement, Nuccaleena Formation, South Australia. $\square$ B. Tepee-like structure, interpreted by Allen \& Hoffman (2005) as a megaripple formed by massive storms, with intervening marine cement, Nuccaleena Formation. $\square$ C. Crystal fans, pseudomorphic after aragonite, Ravensthroat Formation, Mackenzie Mountains, northwestern Canada. (Note ruler and pocket knives for scale.)

on the Marinoan ice age include recent U-Pb dates of ca. $635.5 \pm 1.2 \mathrm{Ma}$ (Hoffmann et al. 2004) and $663 \pm 4 \mathrm{Ma}$ (Xiao et al. 2003) from ash beds within and beneath glacial strata, respectively, and $\mathrm{U}-\mathrm{Pb}$ ages of $635.2 \pm 0.6$ $\mathrm{Ma}$ and $621 \pm 7 \mathrm{Ma}$ for zircons in ash beds within and immediately above the cap carbonate that veneers Nantuo tillites in southern China (Condon et al. 2005; Zhang et al. 2005; see also Yin et al. 2005, who report an age of $628.3+/-5.8 \mathrm{Ma}$ for an ash bed 'near the base of the Doushantuo Formation'). U-Pb dates also indicate later glaciation of regional extent (Bowring et al. 2003).

Patterns of C-isotopic variation as well as the lithological features of cap carbonates serve to distinguish among glacial deposits of differing ages (Kennedy et al. 1998; Halverson et al. 2005). Thus, GSSP placement above a Marinoan diamictite-bearing unit in South Australia does not introduce intractable problems of correlation - quite the opposite. Records of Marinoan glaciation outside of Australia include the Nantuo Formation in China (Wang et al. 1981; Jiang et al. 2003a, 2003b), Laplandian deposits in Russia (Chumakov 1990), the Ghaub Formation in Namibia (Hoffman et al. 1998; Kennedy et al. 1998), the Wilsonbreen Formation in Spitsbergen and its equivalents in central East Greenland (Fairchild \& Hambrey 1995), at least the upper part of the Blaini Formation in India (Gupta \& Kanwar 1981; Kumar et al. 2000; Jiang et al. 2003b), and the Ice Brook Formation in northwestern Canada (Aitken 1991; Narbonne \& Aitken 1995; James et al. 2001). In contrast, the Moelv (Nystuen 1976; Knoll 2000) and upper Varanger diamictites in Scandinavia and the Gaskiers Formation (Eyles \& Eyles 1989) in Newfoundland appear to record a younger, regional event centered on the peri-North Atlantic (Halverson et al. 2005); U-Pb dates on ash beds below, within, and above the Gaskiers Formation, indicate that this short-lived event took place about 580 million years ago (Bowring et al. 2003; Condon et al. 2005).

Biostratigraphy. - The tools for correlation in terminal Proterozoic successions, thus, include biostratigraphy, chemostratigraphy, and event stratigraphy, especially rocks that reflect high amplitude shifts in global climate. Magnetostratigraphy has promise, as well (Kirschvink \& Rozanov 1984), but its potential remains to be developed. There is broad agreement that fossils of the Ediacara Biota (Fig. 1A, B) provide compelling characterization of the terminal Proterozoic interval. Save for small discoidal structures of uncertain origin in northwestern Canada (Hofmann et al. 1990), Ediacaratype megafossils are unknown in pre-Marinoan successions. Equally, only a few taxa of Ediacara-grade organisms are known to have survived into the Cambrian Period. Diverse and structurally complex fossils of the Ediacara Biota have been discovered in some 25 localities and areas distributed globally, and the presence of diverse Ediacara assemblages reliably indicates a terminal Proterozoic age (Fedonkin 1990; Narbonne 1998). On the other hand, 25 occurrences in 32 million years is a sparse record. Statistical methods are available to place error bars on first and last appearances of fossil taxa (e.g. Strauss \& Sadler, 1989; Marshall 1990), and applied even in general fashion to the Ediacaran fossil record, these indicate a stratigraphic uncertainty of many millions of years in the correlation of first appearances of diverse Ediacara taxa in different basins. Thus, while fossils of the Ediacara Biota compellingly characterize the Ediacaran Period, they do not provide sharp tools for initial GSSP definition. 


\section{South China}
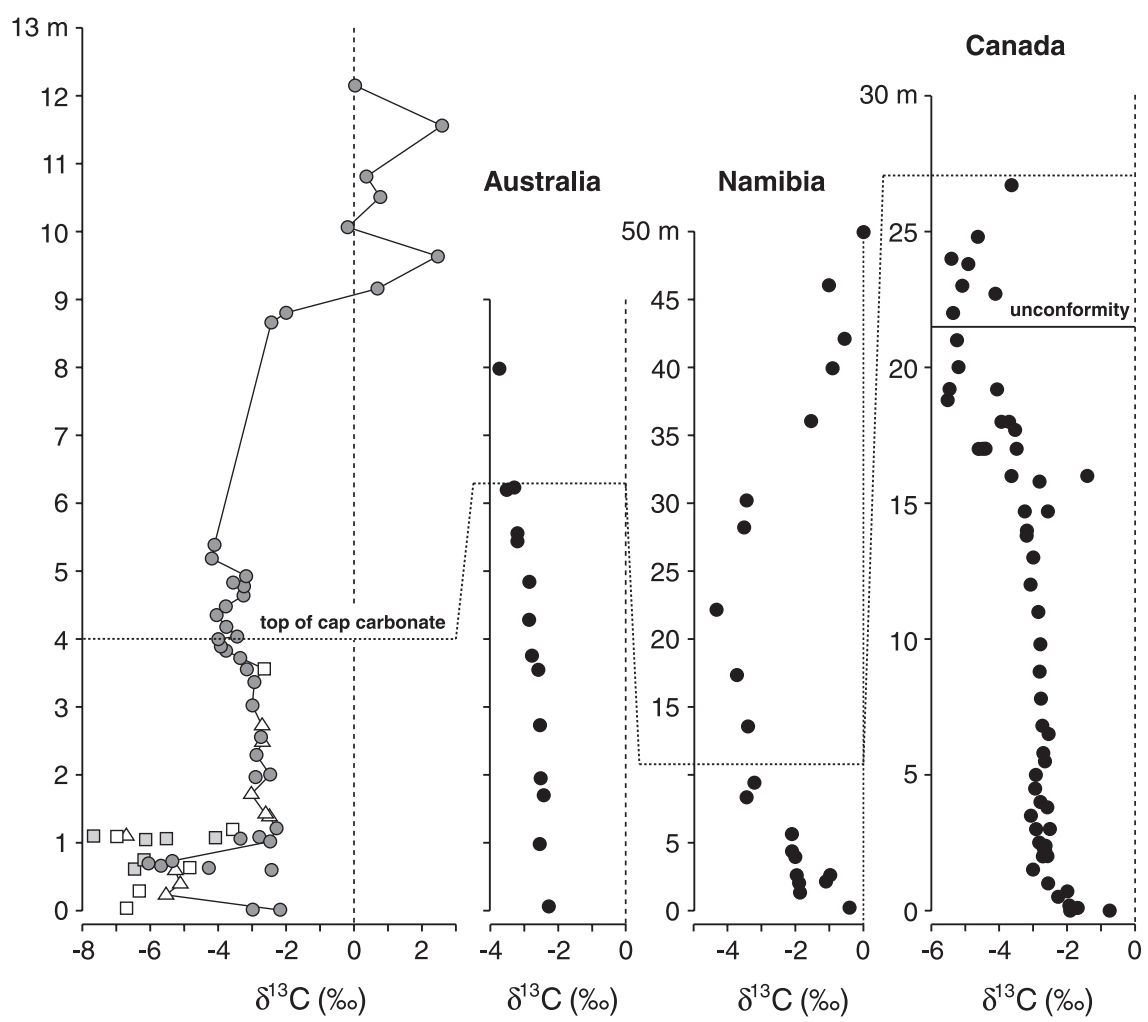

Fig. 3. Examples of carbon isotopic profiles for sections of Marinoan cap carbonate in South China (Doushantuo Formation, section 9 of Jiang et al. 2003), Australia (Nuccaleena Formation, Enorama Creek GSSP; M.J. Kennedy, personal communication 2004), Namibia (Maieberg Formation, Duurwater; Kennedy et al. 1998), and Canada (Ravensthroat and Hayhook formations, Redstone Plateau, Mackenzie Mountains; James et al. 2001). The sections are arranged in order of increasing cap thickness ( 4 to $26.5 \mathrm{~m}$; note scale changes). Symbols for China: filled circles, dolomicrite; filled squares, internal sediment in voids; open squares, isopachous or botryoidal cements in voids; triangles, sparry dolomite. $\delta^{13} \mathrm{C}$ values decrease upward through the cap carbonate in each profile (from near $0 \%$ in the thickest sections to $<-5 \%$ ), and where overlying carbonate rocks are present, returns to zero within $10-50 \mathrm{~m}$ (China and Namibia). The cap carbonate interval is designated on the basis of compositional, textural and structural criteria, as well as on stratigraphic position.

Much the same can be said of other biostratigraphic indicators. Among the oldest unambiguous records of animal life are eggs, embryos, and camerate tubes found in phosphorites of the Doushantuo Formation, China, that lie stratigraphically above Nantuo diamictites (Xiao \& Knoll 2000; Xiao et al. 2000). Barfod et al. (2002) obtained a $\mathrm{Pb}-\mathrm{Pb}$ date of $599 \pm 4$ million years for the fossiliferous beds, although in combination, carbon isotopes and recent $\mathrm{U}-\mathrm{Pb}$ dates on Doushantuo ash beds suggest an age range of ca. 560-580 Ma, overlapping with early Ediacara assemblages in Newfoundland. Trace fossils and calcified megafossils (e.g. Cloudina) are widely distributed in younger rocks of terminal Proterozoic age, but have not been identified unequivocally in rocks older than 555 million years (Martin et al. 1999). While they may in time prove useful in the subdivision of the Ediacaran Period, these remains do not help to define its beginning. Diverse assemblages of morphologically complex acritarchs are also known from older Ediacaran rocks on several continents (Fig. 1C, D; Vidal 1990; Jenkins et al. 1992;
Zang \& Walter 1992; Zhang et al. 1998; Grey 2005), and in Australia, at least, their stratigraphic distribution allows for the recognition of several assemblage zones (Grey 2005). But, once again, statistical evaluation of first appearances yields large error bars. Stromatolites, seaweeds, hydrocarbon biomarkers of algae, and prokaryotic microfossils all occur in terminal Proterozoic rocks, but none provides a high resolution guide to boundary definition.

In summary, then, fossils provide an increasingly refined view of life just before the Cambrian explosion, and they suggest ways that the terminal Proterozoic period might be subdivided, but biostratigraphy does not provide a strong basis for boundary definition at present, and the prospect that it will do so in the future is small.

Chemostratigraphy. - The pronounced stratigraphic variation in C-isotopic compositions of Neoproterozoic carbonates and organic matter was first identified nearly two decades ago (Knoll et al. 1986), and since that time, 
numerous studies have refined our understanding of secular changes in the Neoproterozoic carbon cycle (for a recent summary, see Walter et al. 2000). In particular, the isotopic record of terminal Proterozoic carbonates is well-established (e.g. Kennedy 1996; Kaufman et al. 1997; Calver, 2000; Halverson et al. 2005). It begins with $\delta^{13} \mathrm{C}$ values of ca. +1 to $-3 \%$ that decline upsection within post-Marinoan cap carbonates to values as low as $-8 \%$, before beginning a climb to values as high as + $8 \%$ (Fig. 3). In combination with unusual carbonate depositional textures, barite deposition, and rising ${ }^{87} \mathrm{Sr} /{ }^{86} \mathrm{Sr}$, this C-isotopic pattern provides a unique geological signature of Marinoan deglaciation (Kennedy et al. 1998; Halverson et al. 2005; Jiang et al. 2003a). Even meter-thick caps deposited at high latitudes contain the full range of $\mathrm{C}$-isotopic variation documented in thick, low latitude sections, suggesting that the variable thicknesses of cap carbonates in different areas commonly reflect variations in depositional rate rather than a measurably later onset of precipitation (Porter et al. 2003). Geochemical controls on post-glacial isotopic variation remain contentious (e.g. Grotzinger \& Knoll 1995; Hoffman \& Schrag 2002; Jiang et al. 2003a; Ridgwell et al. 2003), but all proposed explanations involve geologically rapid glacial decay. Given mixing times on the order of $10^{3}$ years for ocean water (Broecker \& Peng 1982), the large isotopic variations seen globally suggest a level of synchroneity that rivals the best available for Phanerozoic biostratigraphy.

\section{The Global Stratotype Point and Section for the initial boundary of the Ediacaran Period}

Formal statement of name and GSSP placement. - The beginning of the terminal Proterozoic period is defined as the base of the Marinoan cap carbonate (Nuccaleena Formation) in the Enorama Creek section of the central Flinders Ranges, Adelaide Rift Complex, South Australia (Figs. 4-6). This time interval shall be known as the Ediacaran Period, in recognition of its transcendent characteristic, the Ediacara Biota.

The Nuccaleena is the lowermost division of the $3 \mathrm{~km}$ thick terminal Proterozoic Wilpena Group in the Flinders Ranges (Fig. 5). It overlies a varied assemblage of glacial, glacial-marine and associated deposits assigned to the Elatina Formation (and correlative units) at the top of the Umberatana Group (Preiss 1987). The entire section, more than $8 \mathrm{~km}$ thick, from Sturtian glacial deposits in the lower part of the Umberatana Group, to the base of the Cambrian (top of the Wilpena Group), is exposed in a single west-dipping homocline, encompassing the Enorama Creek locality (Figs 4 and 6; Preiss 1999; Reid \& Preiss 1999).

The main advantages of this section are clear palaeontological, sedimentological, and carbon isotopic context; expanded stratigraphic thickness; simple structure well known from both regional and local geological mapping; excellent exposure in semi-arid terrain; historical significance; and ease of access. In common with all of the prime candidates for a terminal Proterozoic GSSP, the main limitation of the Flinders Ranges is the absence of datable igneous rocks in the relevant portion of the stratigraphy. However, precise global correlation at the cap level using carbon isotopic data should eventually make it possible to constrain the age of the proposed GSSP. As noted above, the end of Marinoan glaciation is constrained from below by a $635.5 \pm 1.2 \mathrm{Ma}$ $\mathrm{U}-\mathrm{Pb}$ zircon age for an ash bed within glacial strata in Namibia (Hoffmann et al. 2004), and dates of 635.2 \pm $0.5 \mathrm{Ma}$ and $621 \pm 7 \mathrm{Ma}$ for ash beds within and just above the post-Nantuo cap carbonate in China constrain the age of Marinoan deglaciation from above (Condon et al. 2005; Zhang et al. 2005).

Detailed description of GSSP. - The cap carbonate at the base of the Nuccaleena Formation is well exposed and easily recognized throughout the Flinders Ranges. From a practical point of view, it makes little difference which section is selected for a stratotype. Among the best candidates are Chambers Gorge, Trezona Bore, and Enorama Creek.

The most spectacular exposures of the cap carbonate are those at Chambers Gorge on the eastern side of the Flinders Ranges (COPLEY 1:250,000 geological map sheet; Coats 1973). Trezona Bore and Enorama Creek on the western flank of the ranges (PARACHILNA 1:250,000 geological map sheet; Reid \& Preiss 1999) have the advantages of a very simple structural setting, a full stratigraphic context, ease of access, and the protection afforded by a location within the Flinders Ranges National Park (Figs 4 and 6). The west-dipping homocline of the west-central Flinders Ranges is dissected by both east-west and north-south valleys. Expanded sections of pre-glacial Trezona and Yaltipena formations, glacial Elatina Formation and post-glacial Brachina Formation are well exposed and documented in a salt-withdrawal syncline (Preiss 1987; Lemon \& Gostin 1990; Christie-Blick et al. 1995; Lemon \& Reid 1998; Sohl et al. 1999; Sohl 2000). The most favorable section overall at this stratigraphic level is a composite section in the vicinity of Trezona Bore, but the greater thickness of the cap carbonate and accessibility of the Enorama Creek locality by road lead us to designate that section as the GSSP (Figs 6-8). The location, determined by stand-alone Global Positioning System, is 


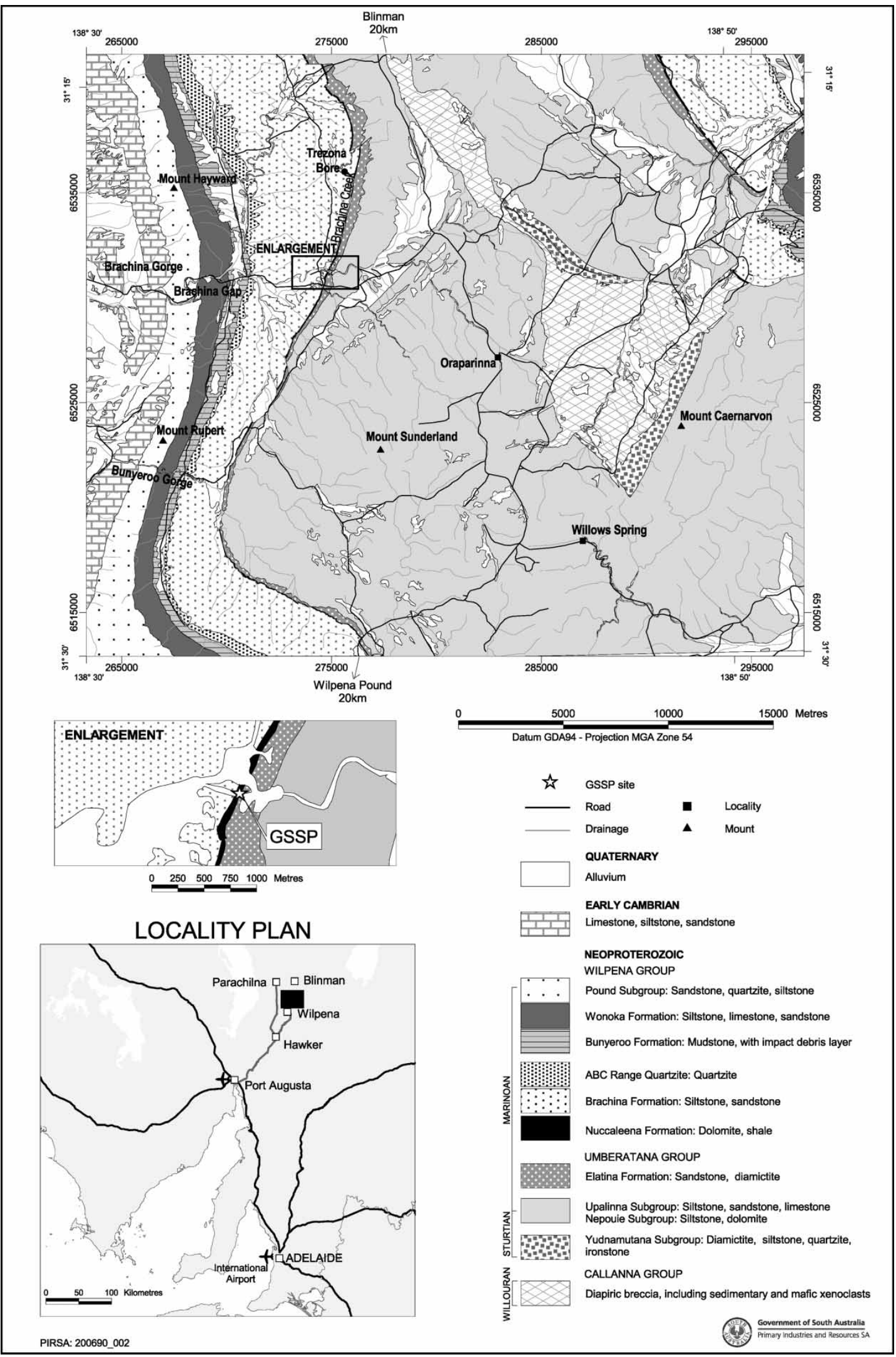

Fig. 4. Location map of the Enorama Creek locality (from Reid \& Preiss 1999), with insets showing an enlargement of the proposed GSSP site and location within a broader area of South Australia. 


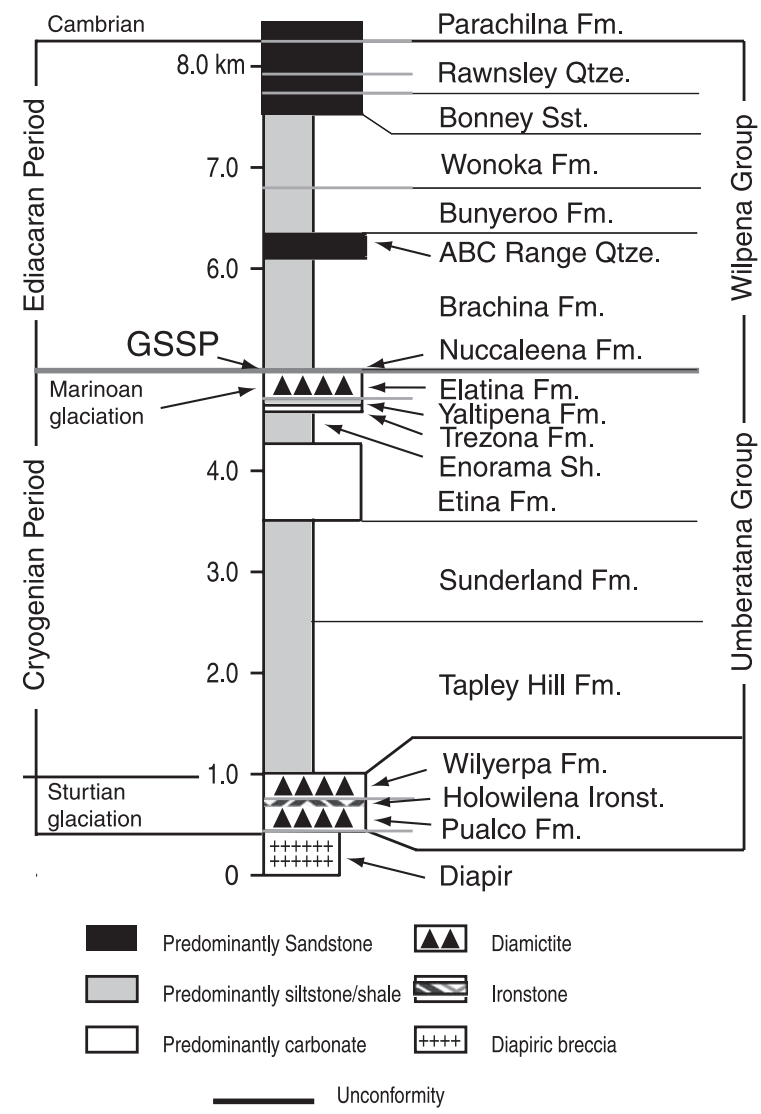

Fig. 5. Generalized stratigraphic section for the Umberatana and Wilpena groups of the central Flinders Ranges, South Australia, essentially as exposed in the homocline that contains the GSSP. Diagram indicates the stratigraphic placement of the GSSP within the broader upper Neoproterozoic stratigraphy of the region.

Zone 54, 274825 $\pm 5 \mathrm{mE}, 6531235 \pm 5 \mathrm{mN}$ (GDA 94), or $31^{\circ} 19^{\prime} 53.2^{\prime \prime} \mathrm{S}, 138^{\circ} 38^{\prime} 0.2^{\prime \prime} \mathrm{E}$.

Access to Enorama Creek is by paved road from Adelaide, the closest city with an international airport, $400 \mathrm{~km}$ to the south, and by well-maintained unpaved roads within the Flinders Ranges National Park. It is less than a day's drive from Adelaide. The Flinders Ranges is a tourist region visited by tens of thousands of people every year. Motels, hotels, camping grounds and shops are available in several places. The tourist resort at Wilpena Pound provides a convenient local base.

Geological location. - The Flinders Ranges are made up of rocks of the Neoproterozoic to Middle Cambrian Adelaide Rift Complex (formerly Adelaide Geosyncline). The geology of this region has been studied intensively for more than a century. Geological maps at 1:250,000 and 1:63,360 scale (Dalgarno et al. 1964; Dalgarno \& Johnson 1965, 1966) are currently available from the Geological Survey of South Australia (now Primary Industries and Resources South Australia) and elsewhere. The recently published second edition of the
PARACHILNA 1:250,000 geological map (Reid \& Preiss 1999) with Explanatory Notes (Preiss 1999) incorporates the area of the proposed GSSP. There is a large published literature on the region, including numerous monographs. This has recently been synthesized in a series of volumes (Preiss 1987, 1990, 1993). Color aerial photographs and satellite imagery are readily available.

The Ediacara Biota (Fig. 1A, B) is generally regarded as the prime distinguishing characteristic of the terminal Proterozoic (no matter how such a unit might be defined). With the single possible exception of a dubious pennatulid-like fossil found $26 \mathrm{~m}$ below the base of the Nuccaleena Formation at Horrocks Pass near Wilmington (Dyson 1985), subsequently regarded as inorganic (Jenkins 1986), and the contentious structure Bunyerichnus dalgarnoi Glaessner low in the Wilpena Group (see Fig. 5 for stratigraphic units), all known examples of the Ediacara Biota in South Australia have been described from the upper part of the Wilpena Group (Jenkins 1995), with the best known members of the assemblage being restricted to the Pound Subgroup in the upper part of the Wilpena Group.

Searches for pre-Marinoan fossils of similar aspect in this region and in central and northern Australia have a history, and over the last 30-40 years in particular such searches have been repeated and intensive. None has been found at these lower stratigraphic levels; nor have sedimentological studies conducted over the same period revealed any convincing reason why such fossils should go unpreserved. Thus it is reasonable to conclude that such organisms were rare or absent prior to the time of deposition of the Wilpena Group. Selection of a GSSP at or near the base of the Wilpena Group would therefore include in the Ediacaran Period all definite Ediacara-type fossils known in Australia and all global occurrences of the Ediacara Biota as conventionally recognized.

Also encompassed by such a definition of the terminal Proterozoic is the distinctive acritarch assemblage of the Pertatataka Formation in the Amadeus Basin and correlative levels in the Officer Basin and on the Stuart Shelf of the Adelaide Rift Complex (Jenkins et al. 1992; Zang \& Walter 1992; Grey 2005; Grey et al. 2003). This assemblage includes some 50 taxa, mostly very large and many highly ornamented (Fig. 1C, D). It has not been recognized in the Flinders Ranges, partly because of deeper burial and thermal alteration of the sediments, but largely because of a lack of fresh drill core. The acritarch-bearing interval is considered to correspond with the Bunyeroo and Wonoka Formations in the middle part of the Wilpena Group. Correlations with the Officer Basin are well established, especially at the level of the impact ejecta layer in the lower part of the Bunyeroo Formation, a distinctive deposit that has been linked to an impact structure at Lake Acraman in the 


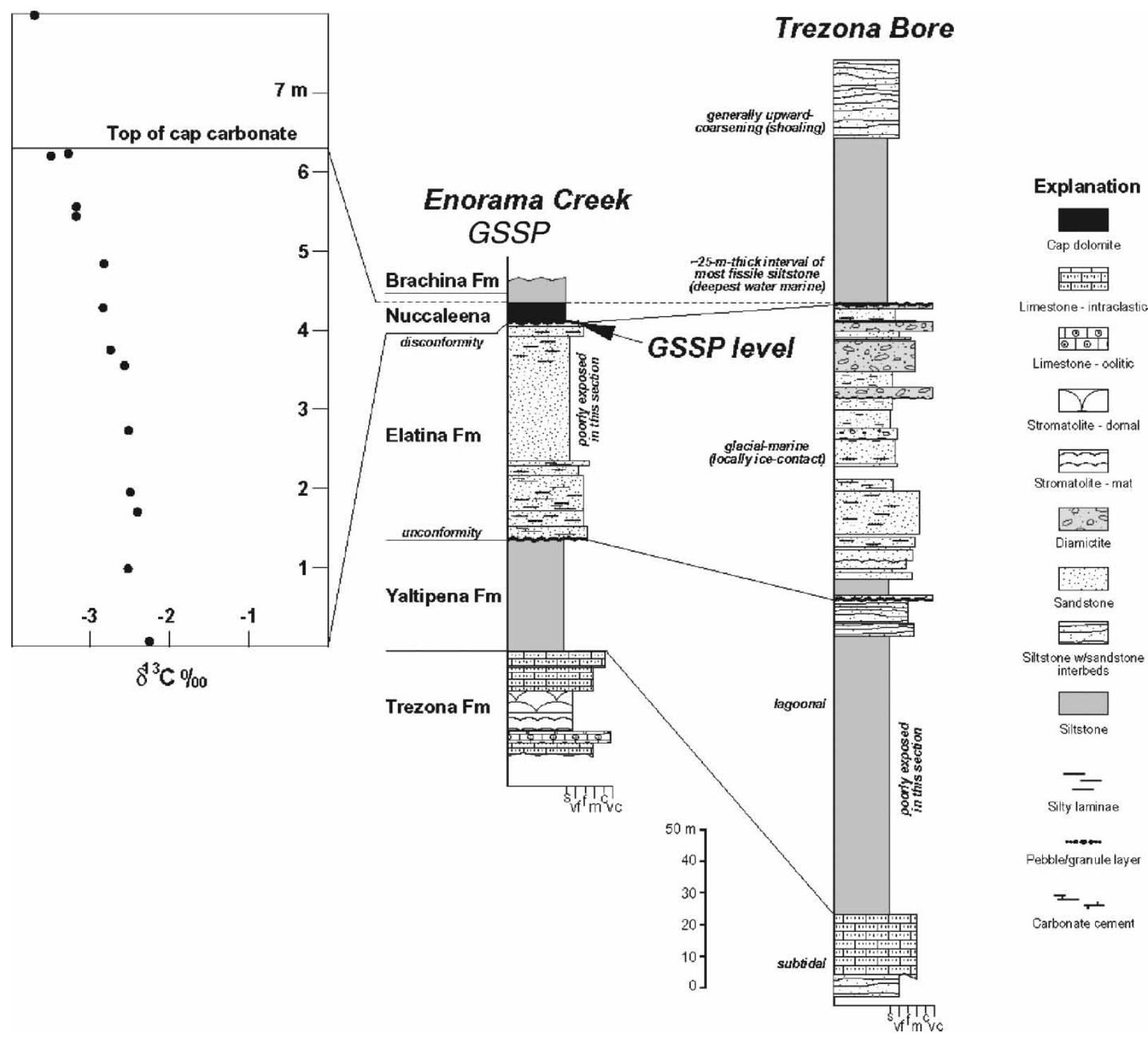

Fig. 6. Stratigraphic sections at Enorama Creek and Trezona Bore (5 km to north), with carbon isotopic profile for Enorama Creek (M.J. Kennedy, unpublished isotopic data). Note that the Nuccaleena Formation formally includes an interval of greyish red siltstone with thin beds of dolostone in the transition to the overlying Brachina Formation. A nearly complete composite section may be pieced together for the Neoproterozoic in this part of the Flinders Ranges, starting in the upper part of the Sturtian glacial succession.

Gawler Ranges west of the Flinders Ranges (Gostin et al. 1986; Williams 1986; Wallace et al. 1989; Grey et al. 2003). Acritarchs have also been found in the preserved portion of this same interval on the intervening Stuart Shelf, where the rocks are undeformed and have never been deeply buried, and abundant drill core is available (Zang 1997; Grey 2005; Grey et al. 2003). Most, and perhaps all, convincing glaciogenic deposits known from the Flinders Ranges and correlative units elsewhere in Australia underlie the Wilpena Group and its equivalents. The well known Sturtian glacial deposits substantially pre-date the Wilpena Group (Preiss 1987, 1990; Young \& Gostin 1991; Preiss 1993), and the Marinoan glacial deposits immediately underlie it (Mawson 1949;
Preiss et al. 1978; Preiss 1987, 1990, 1993; Lemon \& Gostin 1990).

The Marinoan Elatina Formation is of particular significance for yielding the most convincing evidence to date for continental glaciation at low latitude $\left(7.5^{\circ} \mathrm{N}\right.$. with error limits of $1.0^{\circ}$ to $14.5^{\circ} \mathrm{N}$.; Schmidt \& Williams 1995; Sohl et al. 1999). One of three key palaeomagnetic reference sections is located $5 \mathrm{~km}$ north of the proposed GSSP near Trezona Bore (Figs 3 and 5).

The Marinoan is the last global glaciation of the Neoproterozoic, and as such marks a critical boundary in Earth evolution. DiBona (1991) reported diamictite and lonestones in laminated siltstone in the upper part of the Wilpena Group of the northern Flinders Ranges, 


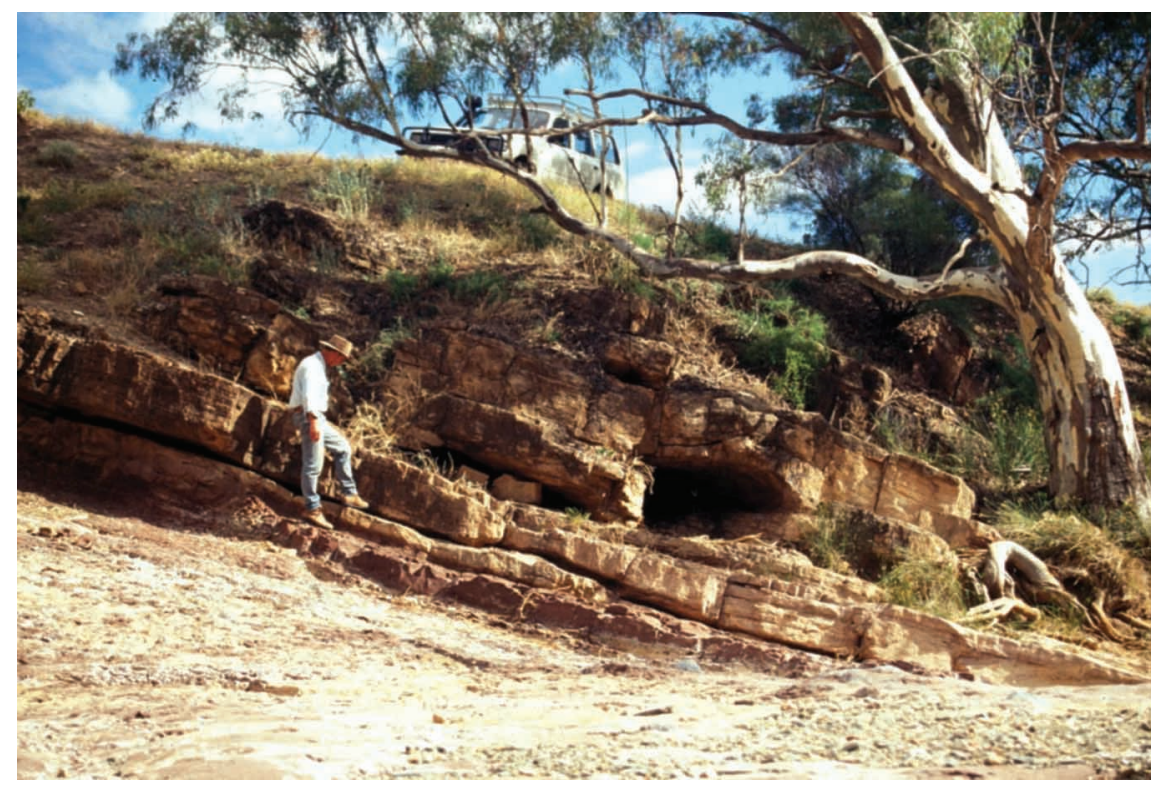

Fig. 7. Outcrop view of Enorama Creek section, showing the Nuccaleena cap carbonate overlying the uppermost diamictites. The right foot of the geologist stands on the top of the uppermost diamictite bed; the GSSP falls within the layer on which his left rests, at a point where carbonate cemented siltstone is topped by pure carbonate containing sheet cracks (see Fig. 7). At Enorama Creek, the uppermost dimictite is overlain by $0.85 \mathrm{~m}$ of grayish red, very fine grained sandstone and siltstone with current ripples, parallel laminae and wavy laminae. Regional mapping places this unit with the Elatina and separate from the precipitated carbonate layer above it.

and inferred that they might be of glacial origin. However, the restricted distribution of these deposits and their sediment gravity flow association cast doubt on the glacial interpretation. Grey \& Corkeron (1998) proposed that the youngest glaciation in the Kimberley region of northwestern Australia could be post-Marinoan on the basis of correlation using the distinctive stromatolite Tungussia julia. This correlation, however, requires testing.

The Marinoan cap carbonate is a distinctive stratigraphic unit located at the base of the Nuccaleena Formation and locally within the correlative Seacliff Sandstone. It is well exposed and readily mapped in the Flinders Ranges over many hundreds of square kilo-

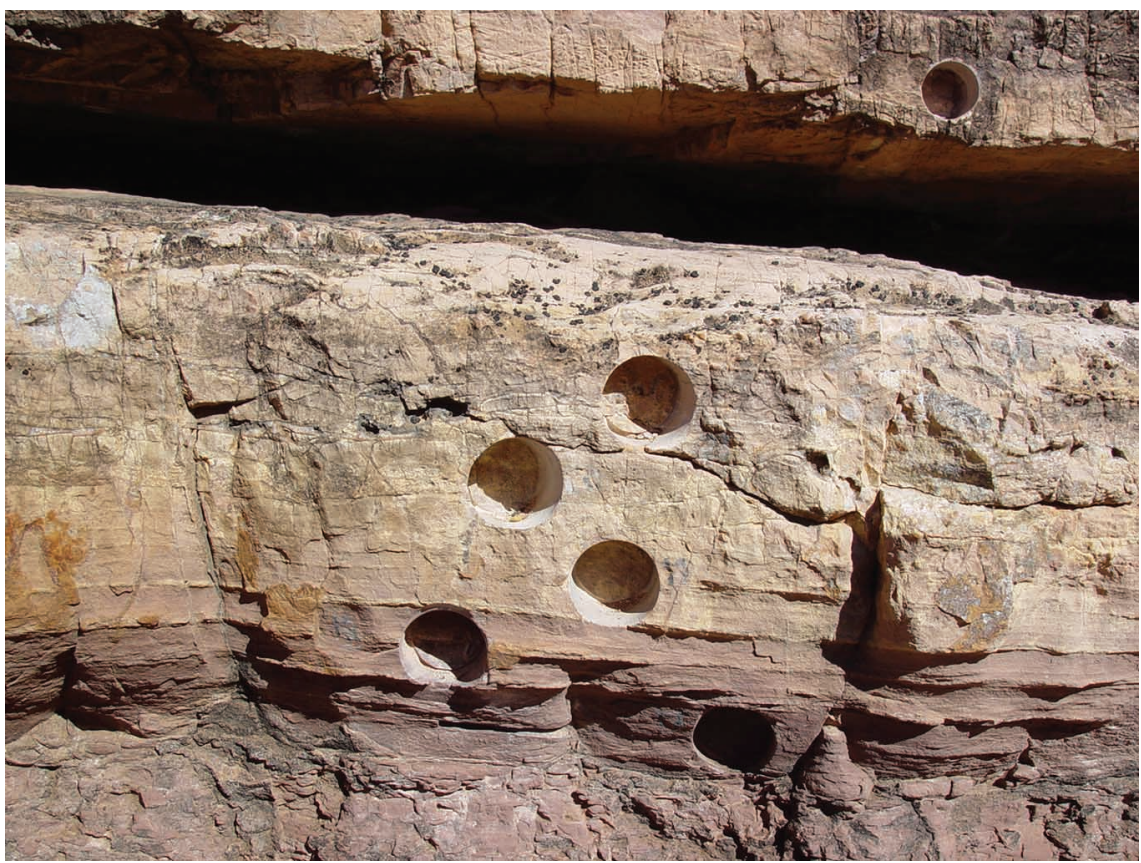

Fig. 8. Closer view of GSSP level within Enorama Creek section. GSSP level is just below the mid-point of the fourth paleomag drill hole from the bottom, where carbonate cemented siltstone is overlain by sheet-cracked carbonate. 
meters. The carbonate is typically no more than a few meters thick and is composed primarily of finely laminated cream and pink microspar and dolomicrite (Plummer 1979; Williams 1979; Preiss 1987, 1990, 1993; Lemon \& Gostin 1990; Dyson 1992; Kennedy 1996; Calver 2000). The most common facies consists of normally graded event layers (turbidites), in places arranged into constructional meter-scale tepee-shaped structures aligned parallel with paleocurrents (Fig. 2). Less common, but found widely within the Nuccaleena and cap carbonates in general, are facies characterized by abundant sheet cracks, bedding disruption, brecciation, multiple generations of isopachous fringing cements and internal sediments, stromatolites, formerly aragonite and barite crystal fans and tube-like structures features that have been attributed recently to the development of cold methane seeps at the cap level (Kennedy et al. 2001b; see also Jiang et al. 2003a). In contrast to early interpretations of the carbonate as locally peritidal (Plummer 1979), the Nuccaleena is now thought to have accumulated in many tens to perhaps hundreds of meters of water. Shallow-water indicators are absent. The lower contact of the Nuccaleena is a disconformity, tentatively attributed to post-glacial isostatic rebound (Christie-Blick et al. 1995). The carbonate is interpreted to represent a short-lived chemical oceanographic event accompanying Marinoan deglaciation and sea-level rise, and to be of global extent. This interpretation, foreshadowed by the work of R.P. Coats (Geological Survey of South Australia) in the 1960s and 1970s (Preiss et al. 1978; Coats \& Preiss 1980), is now supported by the recognition in the cap carbonate of a very distinctive carbon isotopic signature, with $\delta^{13} \mathrm{C}$ values that decrease upwards from close to $0 \%$ at the base to values of $-5 \%$ or lower (Fig. 3; Kennedy 1996; Calver 2000; Walter et al. 2000; McKirdy et al. 2001). The emerging picture of cap carbonates as high-resolution global markers (Preiss et al. 1978; Williams 1979; Coats \& Preiss 1980, 1987; Knoll et al. 1986; Kaufman et al. 1993, 1997; Narbonne et al. 1994; Grotzinger \& Knoll 1995; Narbonne \& Aitken 1995; Kennedy 1996; Hoffman et al. 1998; Kennedy et al. 1998, 2001a,b; Calver 2000; Calver \& Walter 2000; Walter et al. 2000; Halverson et al. 2004) makes the Marinoan cap extremely attractive for defining a GSSP.

Although carbonate rocks are only locally developed within the Umberatana and Wilpena groups of the Flinders Ranges below and above the Marinoan cap level, the carbon isotopic systematics of these units have been studied independently by at least three different research groups over the past decade, and are now well known (see summaries by Calver 2000; Walter et al. 2000; McKirdy et al. 2001; and the discussion by M.J. Kennedy in 12th Circular of the ICS Subcommission on the Terminal Proterozoic Period, 1999).
Stratigraphic level of GSSP. - If the cap carbonate represents time on the order of $10^{4}$ to $10^{5}$ years, as some have suggested (Kennedy \& Christie-Blick 1998; Kennedy et al. 2001b), at the age resolution usually achievable in Proterozoic rocks the precise level selected within the cap is of little consequence. Following Cloud \& Glaessner (1982); see also Christie-Blick et al. 1995), then, the initial GSSP for the Ediacaran Period has been placed at the base of the Nuccaleena Formation (Figs. 4 and 5). Several reasons prompt this choice: (1) The base of the Nuccaleena is a well-defined surface, easily recognized throughout the Flinders Ranges. If related to glacial-isostatic rebound, the associated hiatus is likely to be limited in most places compared, for example, with the erosion surface beneath the Marinoan glacial rocks, because deglaciation was clearly associated with a marked rise in sea level; (2) The lateral variability of absolute $\delta^{13} \mathrm{C}$ values in the cap carbonate is sufficiently great to cast doubt on whether nuances in isotopic data can be used objectively to establish time relations within the carbonate, although, globally, most sections preserve a record of comparable stratigraphic trends in secular variation. Although $\delta^{13} \mathrm{C}$ values attain a minimum near the top of the cap carbonate in those sections elsewhere in which carbonate rocks persist up section above the cap level (e.g. northern Namibia and southern China), that minimum tends to be stratigraphically broad (tens of meters), and not useful for precise correlation; (3) The cap carbonate is thought to represent a chemical oceanographic event, and not simply a sea-level rise. There is no reason to regard the interval of maximum flooding (deepest water) within shales above the cap as having more than regional temporal significance. Nor is it possible to locate any particular distinctive horizon within that interval more objectively than the base of the carbonate.

Taken together, these considerations suggest the base of the Nuccaleena as the level with greatest potential for global correlation. However, a conceptual issue arises with the selection of a disconformity. Would the GSSP correspond in time with the base of the cap carbonate, with the top of the underlying glaciogenic Elatina Formation, or with some point within the span of time not represented at the site selected? The most practical solution is to regard the GSSP as marking the onset of cap carbonate deposition. That is undoubtedly slightly younger than the age of the genetically correlative conformity of the disconformity (Christie-Blick 2001), but it is the criterion of greatest practical utility.

Provisions for conservation, protection, and accessibility. The GSSP is located within the Flinders Ranges National Park and so has special legal protection. The Parks and Wildlife Service of South Australia administer the park and provide rangers to enforce conservation measures. 
Permission must be obtained for rock and fossil sampling, and with the international ratification of the GSSP, conservation regulations will be strictly enforced. Current access is by a well-maintained unsealed road that passes within $100 \mathrm{~m}$ of the GSSP.

Principal correlation events at the GSSP level. - Three distinct but causally related events mark the initial GSSP of the Ediacaran Period. First is the rapid decay of Marinoan ice sheets, clearly observed locally but documented globally. Second is the onset of sedimentologically, texturally, and chemically distinct cap carbonates, again recorded clearly in the GSSP but observed throughout the world. And third is the beginning of the distinctive pattern of secular change in carbon isotopes recorded in the cap carbonates, like the other events documented globally.

Demonstration of regional and global correlation. - The level of the GSSP is recognizable throughout the central and northern Flinders Ranges of South Australia as the base of the Nuccaleena cap carbonate (Preiss 1987). In the southern Flinders Ranges and Mount Lofty Ranges near Adelaide, the Nuccaleena is thought to pass laterally into the Seacliff Sandstone and correlative strata, which appears locally to occupy incised valleys cut into the underlying glacial deposits (Dyson \& von der Borch 1994; Christie-Blick et al. 1995). In those sections, according to the way in which the GSSP is defined above, the base of the Ediacaran System corresponds approximately with the lowest dolomite, typically no more than a few meters to tens of meters below the top of the Seacliff Sandstone. In the Amadeus basin of central Australia, the level of the GSSP corresponds with the base of the cap carbonate at the top of the glaciogenic Olympic Formation (Preiss et al. 1978; Kennedy 1996), and where the cap is missing, approximately with the base of the Pertatataka Formation (marine siltstone comparable to the Brachina Formation in the Flinders Ranges). In the eastern Amadeus Basin, where the Olympic Formation intertongues lithically with the Gaylad Sandstone (Field 1991; Freeman et al. 1991), the cap carbonate is cut out by an unconformity that traces laterally into the Gaylad. This same stratigraphic level corresponds in the Ngalia Basin of central Australia with the cap carbonate in the Mount Doreen Formation. Correlation with the Kimberley region of northwestern Australia is currently unresolved (Grey \& Corkeron 1998).

A decade of intensive research on the cap carbonates that lie above Neoproterozoic glacial deposits has revealed consistent patterns of sedimentology, petrology, and geochemistry that serve to unite caps of similar age and separate caps related to the Sturtian, Marinoan, and Moelv/Gaskiers ice ages (Kennedy et al. 1998; Halverson et al. 2005). Marinoan-age glacial deposits lie above older Neoproterozoic successions characterized by distinctive microfossils (Knoll 2000), carbonate C-isotope compositions that change stratigraphically from unusually positive values (to $+10 \%$ ) to negative values $(-5$ to $-7 \%$ ) just beneath the diamictites (Hoffman \& Schrag 2002; Halverson et al. 2004), and relatively low ${ }^{87} \mathrm{Sr} /{ }^{86} \mathrm{Sr}$ (Kaufman et al. 1993). Strata above Marinoanage glacial deposits contain different, but equally distinctive microfossils (Knoll 2000), all known fossils of the Ediacara Biota (Fedonkin 1990; Narbonne 1998), distinctive C-isotopic profiles (Kaufman et al. 1997; Walter et al. 2000), and much higher ${ }^{87} \mathrm{Sr} /{ }^{86} \mathrm{Sr}$ (Kaufman et al. 1993). Cap carbonates associated with Marinoan-age glacial deposits characteristically have C-isotopic profiles that decline upsection from their base; an upsection transition from pinkish dolostones to limestones, with barite deposits at the transition between lithologies; unusual sedimentary features that include peloidal laminae, 'pseudo-tepees' interpreted by some as aggradational oscillation megaripples, and macroscopic crystalline precipitates (Kennedy 1996; James et al. 2001; Hoffman \& Schrag 2002; Allen \& Hoffman 2005). Caps associated with Sturtian glacial deposits do not exhibit these features, nor do caps (where present) above younger glacial deposits such as the Gaskiers Formation in Newfoundland (Kennedy et al. 1998; Myrow \& Kaufman 1999).

With these features in mind, we suggest that rocks deposited during the Ediacaran Period can be recognized beyond Australia as follows (see Fig. 9 and references cited therein): (1) the cap carbonate above the Nantuo Formation and the succeeding Doushantuo and Dengying formations up to the point of the previously recognized base of the Cambrian; (2) the cap carbonate at the top of the Blaini Formation and the succeeding Infra Krol Formation and Krol Group up to the previously recognized base of the Cambrian in subHimalayan India; (3) the Yudoma Group in Siberia and the Vendian succession in the Ukraine, both of which begin with transgression within the Ediacaran Period; (4) the cap carbonate above the Ghaub Formation in Namibia, succeeding strata of the Tsumeb Subgroup and the Witvlei and Nama groups, up to the previously recognized unconformity marking the base of the Cambrian; (5) the cap carbonate above the Wilsonbreen Formation in Svalbard and its correlatives in central East Greenland and succeeding strata beneath the subCambrian disconformity; (6) the cap carbonate above the Ice Brook Formation in northwestern Canada and succeeding strata of the upper Windermere Subgroup, up to the previously recognized beginning of the Cambrian Period; (7) the Avalon succession in Newfoundland, from the angular unconformity at the base of the Conception Group to the previously recognized 


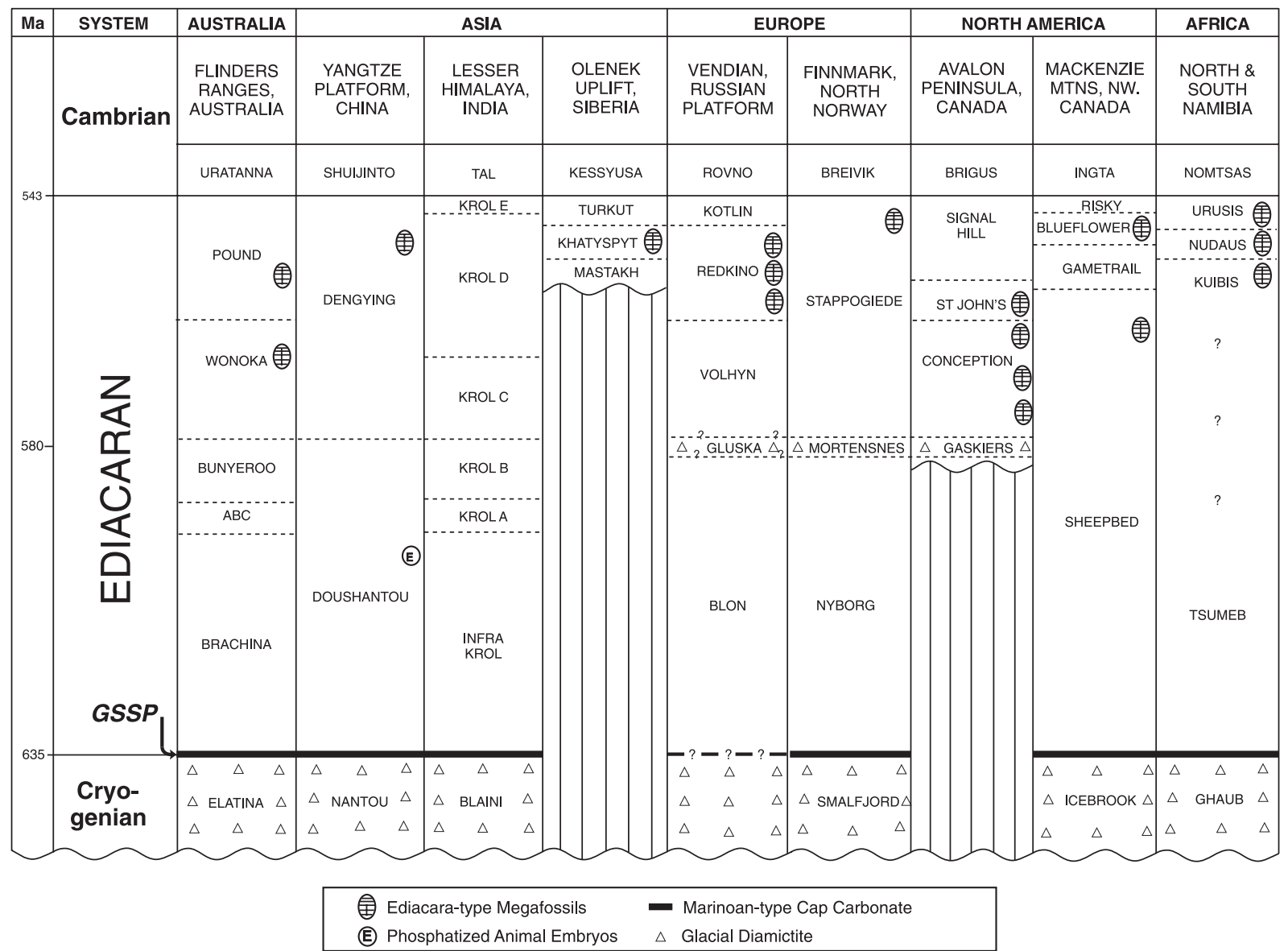

Fig. 9. Correlation of GSSP with other terminal Proterozoic successions, showing the relationship of the proposed Ediacaran period to regional stratigraphic units. The symbol for Cambrian refers to the lowest Cambrian unit overlying the Ediacaran. Sections and correlations from the following sources and references therein: Australia (this report); Yangtze Platform and Lesser Himalaya (Jiang et al. 2003b); Olenek Uplift (Knoll et al. 1995); Vendian type area and Finnmark (Chumakov 1990; Fedonkin 1990; Sokolov 1997; Martin et al. 2000); Avalon Peninsula (Narbonne \& Gehling 2003; Bowring et al. 2003); Mackenzie Mountains (Narbonne \& Aitken 1995); Namibia north (Hoffman et al. 1998) and south (Grotzinger et al. 1995). See these papers, as well, for the positions of unconformities within these successions.

base of the Cambrian; and (8) the cap carbonate above the Smalfjord Formation in northern Norway and overlying strata up to the beginning of the Cambrian.

Age of the GSSP. - Datable igneous rocks have not been identified in the terminal Proterozoic succession of the Flinders Ranges. Attempts have been made to employ $\mathrm{Rb} / \mathrm{Sr}$ systematics on fine-grained siliciclastic rocks from the adjacent Stuart Shelf, but the results are associated with large errors and are in any case likely to reflect maximum ages of deposition owing to the presence of detrital minerals. Shale dates from the deformed rocks of the Flinders Ranges generally reflect the 526-480 Ma Delamerian Orogeny (Chen \& Liu 1996; Flöttmann et al. 1998). Probable ash beds in the Bunyeroo Formation have not yielded zircons (S.A. Bowring \& V. Gostin, personal communication 2004). As noted above, however, recent dates from Namibia and southern China suggest an age for the GSSP younger than $635 \mathrm{Ma}$, but older than $632 \mathrm{Ma}$.
The name of the period. - Termier \& Termier (1960) proposed the name l'Ediacarien for the earliest stage of animal evolution, but no stratotype was defined. Many authors followed this usage. Cloud \& Glaessner (1982) defined the Ediacarian as a system and period. Like Jenkins' (1981) definition of the Ediacaran, their proposed stratotype of the Ediacarian is located in Bunyeroo Gorge in the central Flinders Ranges, approximately 10 $\mathrm{km}$ south-southwest of the currently proposed Enorama Creek locality. The Ediacarian of Cloud and Glaessner encompasses the entire Wilpena Group, consistent with our proposed terminal Proterozoic GSSP, whereas Jenkins' Ediacaran was and is represented by only the upper part of the Wilpena Group. Our proposal can be seen as an extension of the Termier and Termier concept of 1960, and a refinement of that of Cloud \& Glaessner (1982). However, we have adopted the name Ediacaran, believing this to be the etymologically correct form.

The name 'Idiyakra', or 'Ediacara', is Australian Aboriginal in origin and can be traced back to 1859 or 
a little earlier, when the first white pastoralists took up lands in the far north western Flinders Ranges. Its etymology links it to a place where water is or was present close by or about, either in the sense of the present or extending distantly into past wetter times. As water is synonymous with life in the harsh, arid lands of Australia, it is a fitting name for a time when the first megascopic marine animals evolved. As the records of early surveyors and State Parliamentary records show, the ending of the name sounded as a 'kra', 'ker', or 'ka', and hence the appropriate name of the Period is 'Ediacaran' (quoted from R.J.F. Jenkins, unpublished note 2003).

The Flinders Ranges region has come to be regarded as the type area for the Ediacara Biota, despite the fact that elements of it were first recognized in 1872 in Newfoundland by E. Billings, and later in Namibia (see Gehling et al. 2000). Sprigg (1947) contributed the first of a long series of publications about the biota from Australia after his discovery of fossil impressions in the Ediacara Hills, just to the west of the Flinders Ranges.

\section{Conclusions}

The geologic time scale provides formal documentation of our accumulated understanding of Earth history. The downward extension of the geochronological time scale to include the terminal Proterozoic Ediacaran Period thus reflects the extension of that understanding into the once poorly known Precambrian terrains of the world. As now defined, the Ediacaran Period constitutes a distinctive interval of time bounded by two major events, the decay of the great Marinoan ice sheets and the beginning of the Cambrian biological radiation. Biostratigraphic and chemostratigraphic records suggest the feasibility of recognizing at least two series within the period, and it will, as well, be possible to develop a chronostratigraphic definition of the subjacent Cryogenian Period. For these reasons, the ratification of the Ediacaran Period stands as a waypoint in our stratigraphic understanding of Proterozoic rocks, but not its culmination. There is much work still to be done.

Acknowledgements. - The establishment of the Ediacaran Period reflects the coordinated research of many individuals over a period of fourteen years. We thank the voting and corresponding members of the Terminal Proterozoic (now Ediacaran) Subcommission of the ICS, and the many regional experts who helped the subcommission to understand the stratigraphy of key sections on five continents. In particular, we acknowledge the efforts of the late Brian Harland in catalyzing both interest in terminal Proterozoic stratigraphy and in launching the subcommission. We also thank IGCP Project 320 (Neoproterozoic Events and Resources) for financial and intellectual support, John Veevers for comments on an early draft of this manuscript, and Wolfgang Preiss, John Drexel, and Sharon Conner of PIRSA for providing Fig. 4.

\section{References}

Aitken, J.D. 1991: Two Late Proterozoic glaciations, Mackenzie Mountains, northwestern Canada. Geology 19, 445-448.

Allen, P.A. \& Hoffman, P.F. 2005: Extreme winds and waves in the aftermath of a Neoproterozoic glaciation. Nature 433, 123-127.

Barfod, G.H., Alberède, F., Knoll, A.H., Xiao, S., Baker, J. \& Frei, R. 2002: New Lu-Hf and Pb-Pb age constraints on the earliest animal fossils. Earth and Planetary Science Letters 201, 203-212.

Bowring, S., Myrow, P., Landing, E., Ramezani, J., Condon, D. \& Hoffmann, K.H. 2003: Geochronological constraints on Neoproterozoic glaciations and the rise of metazoans. Geological Society of America, Abstracts with Programs 35(6), 517.

Brasier, M., McCarron, G., Tucker, R., Leather, J., Allen, P. \& Shields, G. 2000: New U-Pb zircon dates for the Neoproterozoic Gubrah glaciation and for the top of the Huqf Supergroup, Oman. Geology 28, 175-178.

Broecker, W.S. \& Peng, T.-H. 1982: Tracers in the Sea. 690 pp. LamontDoherty Geological Observatory, Palisades, New York.

Calver, C.R. 2000: Isotope stratigraphy of the Ediacarian (Neoproterozoic III) of the Adelaide Rift Complex, Australia, and the overprint of water column stratification. Precambrian Research 100, 121-150.

Calver, C.R. \& Walter, M.R. 2000: The late Neoproterozoic Grassy Group of King Island, Tasmania: correlation and palaeogeographic significance. Precambrian Research 100, 299-312.

Chen, Y.D. \& Liu, S.F. 1996: Precise U-Pb zircon dating of a post-D2 meta-dolerite: constraints for rapid tectonic development of southern Adelaide fold belt during the Cambrian. Journal of Geological Society, London 153, 83-90.

Chlupác, I. \& Vacek, F. 2003: Thirty years of the first international stratotype: The Silurian-Devonian boundary at Klonk and its present status. Episodes 26(1), 10-15.

Christie-Blick, N. 1997: Neoproterozoic sedimentation and tectonics in west-central Utah. In Link, P.K. \& Kowallis, B.J. (eds): Proterozoic to Recent Stratigraphy, Tectonics and Volcanology, Utah, Nevada, Southern Idaho and Central Mexico. Brigham Young University Geology Studies 42, Part I, 1-30.

Christie-Blick, N. 2001: A personal perspective on sequence stratigraphic nomenclature. American Association of Petroleum Geologists, Hedberg Conference. Dallas, Texas.

Christie-Blick, N., Dyson, I.A. \& von der Borch, C.C. 1995: Sequence stratigraphy and the interpretation of Neoproterozoic Earth history. Precambrian Research 73, 3-26.

Chumakov, N.M. 1990: Laplandian glacial horizon and its equivalents. In Sokolov, B.S. \& Fedonkin, M.A. (eds): The Vendian System, Volume 2: Regional Geology, 199-225. Springer-Verlag, Heidelberg.

Cloud, P.E. \& Glaessner, M.F. 1982: The Ediacarian Period and System: Metazoa inherit the Earth. Science 217, 783-792.

Coats, R.P. 1973: Copley map sheet. Geological Survey of South Australia, Geological Atlas, 1:250 000 Series, sheet SH/54-9.

Coats, R.P. \& Preiss, W.V. 1980: Stratigraphic and geochronological reinterpretation of late Proterozoic glaciogenic sequences in the Kimberley region, Western Australia. Precambrian Research 13, $181-208$.

Coats, R.P. \& Preiss, W.V. 1987: Umberatana Group. In Preiss, W.V. (compiler): The Adelaide Geosyncline. Late Proterozoic Stratigraphy, Sedimentation, Paleontology and Tectonics. Geological Survey of South Australia, Bulletin 53, 125-209.

Condon, D., Zhu, M., Bowring, S., Wang, W., Yang, A. \& Jin, Y. 2005: $\mathrm{U}-\mathrm{Pb}$ ages from the Neoproterozoic Doushantuo Formation, China. Science 308, 95-98.

Dalgarno, C.R. \& Johnson, J.E. 1965: Oraparinna map sheet. Geological Survey of South Australia, Geological Atlas, 1:63 360 Series.

Dalgarno, C.R. \& Johnson, J.E. 1966: Parachilna map sheet. Geological Survey of South Australia, Geological Atlas, 1:250 000 Series, sheet SH54-13. 
Dalgarno, C.R., Johnson, J.E. \& Coats, R.P. 1964: Blinman map sheet. Geological Survey of South Australia, Geological Atlas, 1:63 360 series.

Darwin, C., 1859: On the Origin of Species by Means of Natural Selection. J. Murray, London.

DiBona, P.A. 1991: A previously unrecognised Late Proterozoic succession: Upper Wilpena Group, northern Flinders Ranges, South Australia. Quarterly Geological Notes, Geological Survey of South Australia 117, 2-9.

Dyson, I.A. 1985: Frond-like fossils from the base of the late Precambrian Wilpena Group, South Australia. Nature 318, $283-$ 285.

Dyson, I.A. 1992: Stratigraphic nomenclature and sequence stratigraphy of the lower Wilpena Group, Adelaide Geosyncline: the Sandison Subgroup. Quarterly Geological Notes, Geological Survey of South Australia 122, 2-13.

Dyson, I.A. \& von der Borch, C.C. 1994: Sequence stratigraphy of an incised valet fill: the Neoproterozoic Seacliff Sandstone, Adelaide Geosyncline, South Australia. In Dalrymple, R.W., Boyd, R. \& Zaitlin, B.A. (eds): Incised-Valley Systems: Origin and Sedimentary Sequences. SEPM Special Publication 51, 209-222.

Eyles, N. \& Eyles, C.H. 1989: Glacially-influenced deep-marine sedimentation of the late Precambrian Gaskiers Formation, Newfoundland, Canada. Sedimentology 36, 601-620.

Fairchild, I.J. \& Hambrey, M.J. 1995: Vendian basin evolution in East Greenland and NW Svalbard. Precambrian Research 73, 217-234.

Fanning, C.M. \& Link, P.K. 2003: $700 \mathrm{Ma}$ U-Pb SHRIMP age for Sturtian diamictites of the Pocatello Formation, southeastern Idaho. Geological Society of America, Abstracts with Programs 35(6), 389.

Fedonkin, M.A. 1990: Systematic description of the Vendian metazoans. In Sokolov, B.S. \& Iwanowski, A.B. (eds): The Vendian System, Volume I, 71-112. Springer-Verlag, Heidelberg.

Field, B.D. 1991: Paralic and periglacial facies and contemporaneous deformation of the Late Proterozoic Olympic Formation, Pioneer Sandstone and Gaylad Sandstone, Amadeus Basin, central Australia. In Korsch, R.J. \& Kennard, J.M. (eds): Geological and Geophysical Studies in the Amadeus Basin, Central Australia . BMR Bulletin 236, $127-136$.

Flöttmann, T., Haines, P., Jago, J., James, P., Belperio, A. \& Gum, J. 1998: Formation and reactivation of the Cambrian Kanmantoo trough, SE Australia: implications for early Palaeozoic tectonics at eastern Gondwana's plate margin. Journal of Geological Society, London 155, 525-539.

Freeman, M.J., Oaks, R.Q. \& Shaw, R.D. 1991: Stratigraphy of the Late Proterozoic Gaylad Sandstone, northeastern Amadeus Basin, and recognition of an underlying regional unconformity. In Korsch, R.J. \& Kennard, J.M. (eds): Geological and Geophysical Studies in the Amadeus Basin, Central Australia . BMR Bulletin 236, 137-154.

Gehling, J.G., Narbonne, G.M. \& Anderson, M.M. 2000: The first named Ediacaran body fossil, Aspidella terranovica. Palaeontology 43, 427-456.

Glaessner, M.F. 1966: Precambrian paleontology. Earth-Science Reviews $1,29-50$.

Gostin, V.A., Haines, P.W., Jenkins, R.J.F., Compston, W. \& Williams, I.S. 1986: Impact ejecta horizon within Late Precambrian shales, Adelaide Geosyncline, South Australia. Science 233, 198-200.

Grabau, A.W. 1922: The Sinian System. Bulletin of the Geological Society of China 1, 44-88.

Grey, K. 2005: Ediacaran palynology of Australia. Association of Australasian Palaentologists Memoir 31, 1-439.

Grey, K. \& Corkeron, M. 1998: Late Neoproterozoic stromatolites in glacigenic successions of the Kimberley region, Western Australia: evidence for a younger Marinoan glaciation. Precambrian Research $92,65-87$

Grey, K., Walter, M.R. \& Calver, C.R. 2003: Plankton and isotope changes at the late Neoproterozoic Acraman impact ejecta layer. Geology 31, 459-462.

Grotzinger, J.P. \& Knoll, A.H. 1995: Anomalous carbonate precipitates: Is the Precambrian the key to the Permian? Palaios 10, 578-596.

Grotzinger, J.P, Bowring, S.A., Saylor, B.Z. \& Kaufman, A.J. 1995: Biostratigraphic and geochronological constraints on early animal evolution. Science 270, 598-604.

Gupta, V.J. \& Kanwar, R.C. 1981: Late Paleozoic diamictites of the Kashmir Tethys and Himachal Pradesh Himalaya, India. In
Hambrey, M.J. \& Harland, W.B. (eds): Earth's Pre-Pleistocene Glacial Record, 287-293. Cambridge University Press, Cambridge UK.

Halverson, G.P, Maloof, A.C. \& Hoffman, P.F. 2004: The Marinoan glaciation (Neoproterozoic) in Svalbard. Basin Research 16, 297324.

Halverson, G.P, Hoffman, P.F., Maloof, A.C., Schrag, D.P. \& Rice, A. 2005: Toward a Neoproterozoic composite carbon isotope curve. Geological Society of America Bulletin 117, 1181-1207.

Harland, W.B. \& Herod, K.M. 1975: Glaciations through time. Geological Journal Special Issue 6, 189-216.

Harland, W.B. \& Rudwick, M.S. 1964: The great Infra-Cambrian ice age. Scientific American 211(2), 28-36.

Harland, W.B., Armstrong, R.L., Cox, A.V., Craig, L.E., Smith, A.G. \& Smith, D.G. 1989: A Geologic Time Scale 1989, 263 pp. Cambridge University Press, Cambridge UK.

Hoffman, P.F. \& Schrag, D.P. 2002: The snowball Earth hypothesis: testing the limits of global change. Terra Nova 14, 129-155.

Hoffman, P.F., Kaufman, A.J., Halverson, G.P. \& Schrag, D.P. 1998: A Neoproterozoic snowball earth. Science 281, 1342-1346.

Hoffmann, K.-H., Condon, D.J., Bowring, S.A. \& Crowley, J.L. 2004: A $\mathrm{U}-\mathrm{Pb}$ zircon age from the Neoproterozoic Ghaub Formation, Namibia: Constraints on Marinoan glaciation. Geology 32, 817820.

Hofmann, H.J., Narbonne, G.M. \& Aitken, J.D. 1990: Ediacaran remains from intertillite beds in northwestern Canada. Geology $18,1199-1202$.

James, N.P., Narbonne, G.M. \& Kyser, T.K. 2001: Late Neoproterozoic cap carbonates: Mackenzie Mountains, northwestern Canada: precipitation and global glacial meltdown. Canadian Journal of Earth Sciences 38, 1229-1262.

Jenkins, R.J.F. 1981: The concept of an 'Ediacaran Period' and its stratigraphic significance in Australia. Transactions of Royal Society of South Australia 105, 179-194.

Jenkins, R.J.F. 1986: Are enigmatic markings in Adelaidean of Flinders Ranges fossil ice-tracks? Nature 323, 472.

Jenkins, R.J.F. 1995: The problems and potential of using animal fossils and trace fossils in terminal Proterozoic biostratigraphy. Precambrian Research 73, 51-69.

Jenkins, R.J.F., McKirdy, D.M., Foster, C.B., O’Leary, T. \& Pell, S.D. 1992: The record and stratigraphic implications of organic-walled microfossils from the Ediacaran (terminal Proterozoic) of South Australia. Geological Magazine 129, 401-410.

Jiang, G., Kennedy, M.J. \& Christie-Blick, N. 2003a: Stable isotopic evidence for methane seeps in Neoproterozoic postglacial cap carbonates. Nature 246, 822-826.

Jiang, G., Sohl, L.E. \& Christie-Blick, N. 2003b: Neoproterozoic stratigraphic comparison of the Lesser Himalaya (India) and Yangtze block (south China): Paleogeographic implications. Geology 31, 917-920.

Kaufman, A.J., Knoll, A.H. \& Narbonne, G.M. 1997: Isotopes, ice ages, and terminal Proterozoic earth history. Proceedings of the National Academy of Sciences, USA 94, 6600-6605.

Kaufman, A.J., Jacobsen, S.B. \& Knoll, A.H. 1993: The Vendian record of $\mathrm{Sr}$ and $\mathrm{C}$-isotopic variations in seawater - implications for tectonics and paleoclimate. Earth and Planetary Science Letters 120, 409-430

Kennedy, M.J. 1996: Stratigraphy, sedimentology, and isotopic geochemistry of Australian Neoproterozoic postglacial cap dolostones: Deglaciation $\delta^{13} \mathrm{C}$ excursions, and carbonate precipitation. Journal of Sedimentary Research 66, 1050-1064.

Kennedy, M.J. \& Christie-Blick, N. 1998: Sequence stratigraphy of late Neoproterozoic glacial to post-glacial transition: Implications for the timing of $\delta^{13} \mathrm{C}$ excursions. SEPM-IAS Research Conference (Strata and Sequences on Shelves and Slopes), Catania, Italy.

Kennedy, M.J., Christie-Blick, N. \& Prave, A.R. 2001a: Carbon isotopic composition of Neoproterozoic glacial carbonates as a test of paleoceanographic models for snowball Earth phenomena. Geology 29, 1135-1138.

Kennedy, M.J., Christie-Blick, N. \& Sohl, L.E. 2001b: Are Proterozoic cap carbonates and isotopic excursions a record of gas hydrate destabilization following Earth's coldest intervals? Geology 29, 443446. 
Kennedy, M.J., Runnegar, B., Prave, A.R., Hoffmann, K.-H. \& Arthur, M.A. 1998: Two or four Neoproterozoic glaciations? Geology 26, 1059-1063.

Kirschvink, J.L. \& Rozanov, A.Yu. 1984: Magnetostratigraphy of Lower Cambrian Strata from the Siberian Platform - A paleomagnetic pole and a preliminary polarity time-scale. Geological Magazine 121, 189-203.

Knoll, A.H. 2000: Learning to tell Neoproterozoic time. Precambrian Research 100, 3-20.

Knoll, A.H. \& Walter, M.R. 1992: Latest Proterozoic stratigraphy and earth history. Nature 356, 673-678.

Knoll, A.H., Hayes, J.M., Kaufman, A.J., Swett, K. \& Lambert, I.B. 1986: Secular variation in carbon isotope ratios from the upper Proterozoic succession of Svalbard and east Greenland. Nature 321, 832-839.

Knoll, A.H., Kaufman, A.J., Grotzinger, J.P. \& Kolosov, P. 1995: Integrated approaches to terminal Proterozoic stratigraphy: an example from the Olenek Uplift, northern Siberia. Precambrian Research 73, 251-270.

Kumar, G., Shanker, R., Mathur, V.K. \& Maithy, P.K. 2000: Maldeota section, Mussoorie Syncline, Krol Belt, Lesser Himalaya, India: A candidate for Global Stratotype Section and Point for Terminal Proterozoic System. Geoscience Journal 21(1), 1-10.

Lemon, N.M. \& Gostin, V.A. 1990: Glacigenic sediments of the late Proterozoic Elatina Formation and equivalents, Adelaide Geosyncline, South Australia. In Jago, J.B. \& Moore, P.S. (eds): The Evolution of a Late Precambrian-Early Palaeozoic Rift Complex: The Adelaide Geosyncline. Geological Society of Australia Special Publication 16, 149-163.

Lemon, N.M. \& Reid, P.W. 1998: The Yaltipena Formation of the central Flinders Ranges. MESA Journal 8, 37-39.

Lund, K., Aleinikoff, J.N., Evans, K.V. \& Fanning, C.M. 2003: SHRIMP $\mathrm{U}-\mathrm{Pb}$ geochronology of Neoproterozoic Windermere Supergroup, central Idaho: Implications for rifting of western Laurentia and synchroneity of Sturtian glacial deposits. Geological Society of America Bulletin 115, 349-372.

Marshall, C.R. 1990: Confidence intervals on stratigraphic ranges. Paleobiology 16, 1-10.

Martin, M.W., Grazhdankin, D.V., Bowring, S.A., Evans, D.A.D., Fedonkin, M.A. \& Kirschvink, J.L. 2000: Age of Neoproterozoic bilatarian body and trace fossils, White Sea, Russia: Implications for metazoan evolution. Science 288, 841-845.

Mawson, D. 1949: The Elatina glaciation. Transactions of Royal Society of South Australia 73, 117-121.

McKirdy, D.M., Burgess, J.M., Lemon, N.M., Yu, Xinke, Cooper, A.M., Gostin, V.A., Jenkins, R.J.F. \& Both, R.A. 2001: A chemostratigraphic overview of the late Cryogenian interglacial sequence in the Adelaide fold-thrust belt, South Australia. Precambrian Research 106, 149186.

Myrow, P.M. \& Kaufman, A.J. 1999: A newly discovered cap carbonate above Varanger-age glacial deposits in Newfoundland, Canada. Journal of Sedimentary Research 69, 784-793.

Narbonne, G.M. 1998: The Ediacara biota: A terminal Proterozoic experiment in the evolution of life: GSA Today $8,1-7$.

Narbonne, G.M. \& Aitken, J.D. 1995: Neoproterozoic of the Mackenzie Mountains, northwestern Canada: Precambrian Research 73, $101-$ 121.

Narbonne, G.M. \& Gehling, J.G. 2003: Life after snowball: The oldest complex Ediacaran fossils. Geology 31, 27-30.

Narbonne, G.M., Kaufman, A.J. \& Knoll, A.H. 1994: Integrated chemostratigraphy and biostratigraphy of the Windermere Supergroup, northwestern Canada: Implications for Neoproterozoic correlations and the early evolution of animals. Geological Society of America Bulletin 106, 1281-1291.

Nystuen, J.P. 1976: Facies and sedimentation of the Late Precambrian Moelv Tillite in the eastern part of the Sparagmite region, southern Norway. Norges geologiske undersøkelse 329, 70 pp.

Porter, S.M., Knoll, A.H. \& Affaton, P. 2003: Chemostratigraphy of Neoproterozoic cap carbonates from the Volta basin, West Africa. Precambrian Research 130, 99-112.

Plumb, K.A. 1991: New Precambrian time scale. Episodes 14, 139-140.

Plummer, P.S. 1979: Note on the palaeoenvironmental significance of the Nuccaleena Formation (upper Precambrian), central Flinders
Ranges, South Australia. Journal of Geological Society of Australia 25, 395-402.

Preiss, W.V. (compiler) 1987: The Adelaide Geosyncline. Late Proterozoic stratigraphy, sedimentation, paleontology and tectonics. South Australian Department of Mines and Energy, Geological Survey of South Australia, Bulletin 53, 438 pp.

Preiss, W.V. 1990: A stratigraphic and tectonic overview of the Adelaide Geosyncline, South Australia. In Jago, J.B. \& Moore, P.S. (eds): The Evolution of a Late Precambrian - Early Palaeozoic Rift Complex: The Adelaide Geosyncline. Geological Society of Australia Special Publication 16, 1-33.

Preiss, W.V. 1999: Parachilna, South Australia. Primary Industries and Resources South Australia, Geological Survey of South Australia, Geological Atlas, 1:250 000 Geological Series - Explanatory Notes, sheet SH 54-13, second edition, $52 \mathrm{pp}$.

Preiss, W.V. (compiler) 1993: Neoproterozoic. In Drexel, J.F., Preiss, W.V. \& Parker, A.J. (eds): The Geology of South Australia. Volume 1, The Precambrian: South Australian Department of Mines and Energy, Geological Survey of South Australia, Bulletin 54, 170-203.

Preiss, W.V., Walter, M.R., Coates, R.P. \& Wells, A.T. 1978: Lithological correlations of Adelaidean glaciogenic rocks in parts of the Amadeus, Ngalia, and Georgina basins. BMR Journal of Australian Geology and Geophysics 3, 45-53.

Reid, P.W. \& Preiss, W.V. 1999: Parachilna map sheet. Primary Industries and Resources South Australia, Geological Survey of South Australia, Geological Atlas, 1:250 000 Series, sheet SH 54-13.

Ridgwell, A.J., Kennedy, M.J. \& Caldeira, K. 2003: Carbonate deposition, climate stability, and Neoproterozoic ice ages. Science 302, $859-862$.

Schmidt, P.W. \& Williams, G.E. 1995: The Neoproterozoic climate paradox: Equatorial palaeolatitude for Marinoan glaciation near sea level in South Australia. Earth and Planetary Science Letters 134, $107-124$.

Shanker, R., Bhattacharya, D.D., Pande, A.C. \& Mathur, V.K. 2004: Ediacaran biota from the Jarashi (Middle Krol) and Mahi (Lower $\mathrm{krol})$ formations, Krol Group, Lesser Himalaya, India. Journal of the Geological Society of India 63, 649-654.

Sohl, L.E. 2000: Paleoclimatology of the Neoproterozoic interglacial to Marinoan glacial succession (ca 650-575 Ma), Central Flinders ranges, South Australia. Unpublished $\mathrm{PhD}$ Thesis, Columbia University, New York.

Sohl, L.E., Christie-Blick, N. \& Kent, D.V. 1999: Paleomagnetic polarity reversals in Marinoan (ca. $600 \mathrm{Ma}$ ) glacial deposits of Australia: Implications for the duration of low-latitude glaciation in Neoproterozoic time. Geological Society of America Bulletin 111, 11201139.

Sokolov, B.S. 1952: On the age of the old sedimentary cover of the Russian Platform. Izvestiya Akademii Nauk SSSR, Seriya geologicheskaya 5, 21-31 [in Russian].

Sokolov, B.S. 1984: The Vendian System and its position in the stratigraphic scale. Proceedings of the 27th International Geological Congress (Stratigraphy) 1, 241-269.

Sokolov, B.S. 1997: Essays on the Establishment of the Vendian System, 153 pp. KMK Scientific Press, Moscow [in Russian].

Sprigg, R.C. 1947: Early Cambrian (?) jellyfishes from the Flinders Ranges, South Australia. Transactions of Royal Society of South Australia 71, 212-224.

Strauss, D. \& Sadler, P.M. 1989: Classical confidence intervals and Bayesian probability estimates for the ends of local taxon ranges. Mathematical Geology 21, 411-427.

Termier, H. \& Termier, G. 1960: L’Ediacarien, premier etage paleontologique. Revue Géneral de la Science Pure et Appliqué 67, 79-84.

Vidal, G. 1990: Giant acanthomorph acritarchs from the upper Proterozoic in southern Norway. Palaeontology 33, 287-298.

Walcott, C.D. 1914: Cambrian geology and paleontology II. Smithsonian Miscellaneous Collections 57, 14.

Wallace, M.W., Gostin, V.A. \& Keays, R.R. 1989: Discovery of the Acraman impact ejecta blanket in the Officer basin and its stratigraphic significance. Australian Journal of Earth Sciences 36, $585-587$.

Walter, M.R., Veevers, J.J., Calver, C.R., Gorjan, P. \& Hill, A.C. 2000: Dating the 840-544 Ma Neoproterozoic interval by isotopes of 
strontium, carbon and sulfur in seawater, and some interpretative models. Precambrian Research 100, 371-433.

Wang, Y., Lu, S. \& Gao, Z. 1981. Sinian tillites of China. In Hambrey, M.J. \& Harland, W.B. (eds): Earth's Pre-Pleistocene Glacial Record, 386-401. Cambridge University Press, Cambridge UK

Williams, G.E. 1979: Sedimentology, stable-isotope geochemistry and palaeoenvironment of dolostones capping late Precambrian glacial sequences in Australia. Journal of the Geological Society of Australia $26,377-386$.

Williams, G.E. 1986: The Acraman impact structure: source of ejecta in late Precambrian shales, South Australia. Science 233, 200-203.

Xiao, S. \& Knoll, A.H. 2000: Phosphatized animal embryos from the Neoproterozoic Doushantuo Formation at Weng'an, Guizhou Province, South China. Journal of Paleontology 74, 767-788.

Xiao, S., Yuan, X. \& Knoll, A.H. 2000: Eumetazoan fossils in terminal Proterozoic phosphorites? Proceedings of the National Academy of Sciences, USA 97, 13684-13689.

Xiao, S., Zhou, C., Tucker, R.D., Peng, Z. \& Yuan, X. 2003: Neoproterozoic glaciations and evolution: new data from South China. Geological Society of America Abstracts with Programs 34(7), 517.

Yin, C., Tang, F., Liu, Y., Gao, L., Xing, Y., Yang, Z., Wan, Y. \& Wang, Z. 2005: U-Pb zircon age from the base of the Ediacaran Doushantuo Formation in the Yangtze Gorges, South China: constraint on the age of marinoan glaciation. Episodes 28, 48-49.

Young, G.M. \& Gostin, V.A. 1991: Late Proterozoic (Sturtian) succession of the North Flinders Basin, South Australia; An example of temperate glaciation in an active rift setting. In Anderson, J.B. \& Ashley, G.M. (eds): Glacial Marine Sedimentation: Paleoclimatic Significance. Geological Society of America Special Paper 261, 207222.

Zang, W. 1997: Megascopic carbonaceous Chuaria and Tawuia from the late Neoproterozoic in South Australia. MESA Journal 4, 37-41.

Zang, W. \& Walter, M.R. 1992: Late Proterozoic and Cambrian microfossils and biostratigraphy, Amadeus Basin, central Australia. Memoirs, Association of Australasian Palaeontologists 12, 132 pp.

Zhang, Y., Yin, L., Xiao, S. \& Knoll, A.H. 1998: Permineralized fossils from the terminal Proterozoic Doushantuo Formation, South China. Paleontological Society Memoir 50, 1-52.

Zhang, S., Jiang, G., Zhang, J., Song, B., Kennedy, M.J. \& ChristieBlick, N. 2005: U-Pb sensitive high-resolution ion microprobe ages from the Doushantuo Formation in south China: Constraints on late Neoproterozoic glaciations. Geology 33, 473-476.

\section{Appendix: The process of GSSP selection}

The ICS Working Group on the Terminal Proterozoic Period (now Subcommission) was established at the IGC in Washington in 1989 and included scientists living in 10 different countries on five continents. Over the succeeding decade and a half, the Working Group/Subcommission formally visited terminal Neoproterozoic sections in Ukraine (1990), the Yangtze Platform (1992), the Flinders Ranges (1993 and 1998), central Australia, (1993), Finnmark (1994), Lesser Himalaya (1994), Namibia (1995), and Newfoundland (2001), with additional visits by smaller groups to the White Sea (1995) and the Ural Mountains (1996). The Mackenzie Mountains of northwestern Canada and the Olenek Uplift of Siberia contain outstanding records described by some of the members of the Working Group/Subcommission, but both were regarded as too remote for field trips and consequently neither was nominated as a potential GSSP. Formal meetings of the WG/Subcommission were also held at the IGC in Kyoto (1992) and Beijing (1996). During part of this period, additional investigations and funding were made possible by
IGCP Project 320: Neoproterozoic Events and Resources (led by N. Christie-Blick, M.A. Fedonkin, and M.A. Semikhatov).

A special issue of Precambrian Research edited by Andrew Knoll and Malcolm Walter in 1995 summarized stratigraphic understanding of important successions and techniques, and additional stratigraphic information and reports on all the field excursions have been distributed in seventeen circulars (newsletters) to the more than 150 voting and corresponding members of the Working Group/Subcommission worldwide. A second issue of Precambrian Research, edited by Malcolm Walter in 2000, provided further information on the Neoproterozoic stratigraphy of Australia, including the Flinders Ranges.

After a decade of discussion and field excursions to the principal sites worldwide, a series of increasingly focused ballots were conducted in accordance with ICS regulations. Voter response was excellent, with a participation rate in excess of $90 \%$ of voting members for each of the three ballots and a $100 \%$ return rate for the $3 \mathrm{rd}$ (final) ballot. This speaks highly of the interest and dedication of the voting members, and of the scale of the mandate expressed in the three ballots.

Ballot 1 (December 2000) assessed whether the GSSP of the terminal Proterozoic period should be placed at the base of the Varanger (Marinoan) glacial deposits, at the cap carbonate atop these deposits, at a biostratigraphic level (the first appearance of diverse Ediacaran macrofossils), or at some other level. Level 2, 'the base of, or a horizon within the cap carbonate interval immediately above Varanger (or, Marinoan) glacial beds', was selected by $80 \%$ of the voting members $(89 \%$ of ballots cast on the question), a clear majority under ICS regulations.

Following this, all voting and corresponding members of the Subcommission were invited to submit formal proposals for the location of a GSSP. Four proposals were received: two for sections in the Flinders Ranges in Australia, one for the Yangtze Gorges in China, and one for Lesser Himalaya in India, and all four were published in the 15th TPS Circular. All of these sites had been examined in official visits by the Working Group/Subcommission, and their attributes had been discussed in previous TPP Circulars.

Ballot 2 (March 2003) revealed at least modest support for all of these options, but the greatest support was for the 'Enorama Creek Section, Flinders Ranges, South Australia', which garnered $63 \%$ of votes cast. As this constitutes a valid majority under ICS regulations, it led directly to a 3rd Ballot on this one locality and on the name for the new system and period.

Ballot 3 (September 2003) asked members to vote 'yes' or 'no' on the acceptability of the base of the Nuccaleena Formation in the Enorama Creek section as the GSSP for the Terminal Proterozoic Period and, in a separate question, to vote on their preference among the four names that had been proposed for the Terminal Proterozoic Period. The proposal to fix the position of the GSSP for the Terminal Proterozoic Period 'at the base of the Nuccaleena Formation cap carbonate, immediately above the Elatina diamictite in the Enorama Creek section, Flinders Ranges, South Australia' received 89\% of votes cast, a clear majority under ICS regulations. The name 'Ediacaran' received $79 \%$ of votes cast, also a clear majority under ICS regulations. Voting Members who voted against or 
abstained on the votes for the GSSP proposal or the name were requested to submit a discussion of the reasons for their views, and all responses received were forwarded to the International Commission on Stratigraphy along with the majority report.

A ballot by the full International Commmission on Stratigraphy (February, 2004) also provided a strong mandate for the decision. Votes were 14 'Yes' (88\%), 1 No, and 1 Abstain. The decision was ratified by the IUGS Executive Committee on 12 March 2004.

Other candidate GSSPs and reasons for rejection. - For more than 50 years, the 'Vendian System' has been used to categorize the terminal Neoproterozoic of the East European Platform and elsewhere (Sokolov 1952, 1984, 1997). These strata are largely undeformed and unmetamorphosed, contain worldrenowned assemblages of the Ediacara biota, and have yielded some high-precision U-Pb dates. Despite repeated requests, no proposals were submitted for a 'Vendian' GSSP on the East European Platform. It is difficult to identify a globally correlatable level in this succession that might define a GSSP consistent with the boundary concept approved by a strong majority in Ballot 1. Throughout the East European Platform (e.g. White Sea, Ukraine, and boreholes in the Moscow syneclise) and the Urals, the terminal Neoproterozoic succession consists primarily of siliciclastic rocks with few or no carbonates, and relatively little is known about the chemostratigraphy of these successions. The base of the Vendian, formally defined at the base of the 'Laplandian Tillites', (e.g. Sokolov 1998) is recognizable in surface exposures in Finnmark but in adjacent areas of the East European Platform occurs only in grabens preserved in the subsurface, and is therefore not characterized to the level of surface outcrops of Neoproterozoic glacial deposits elsewhere. Moreover, the concept of placing the terminal Proterozoic GSSP at 'the base of the Varanger (or, Marinoan) glaciogenic succession' was overwhelmingly rejected by the voting members in the 1st Ballot on the grounds that it is extremely difficult to define when a global glaciation began based solely on physical aspects in an isolated section, that the level of first appearance of glacial deposits is wildly diachronous, that there is little biostratigraphic control on the age of onset of glaciation, and that a boundary defined at the base of the last of the Neoproterozoic global glaciations would be less significant in terms of Earth evolution than one that marks their end. Glacial deposits are not present beneath the fossiliferous outcrops of Ukraine, which nonconformably overlie crystalline basement covered with varying thicknesses of arkosic sediments and regolith, and are also not exposed in the White Sea area.

Proposals for locating the GSSP in south China and in the Lesser Himalaya, India, were considered carefully. Both regions are attractive for the wide distribution of terminal Proterozoic rocks, including the Marinoan glacial level and overlying cap carbonate, and in each example passing upward into a carbonate platform many hundreds of meters thick (Jiang et al. 2003a,b). In both regions, a varied biota has been described from Ediacaran strata and the Proterozoic-Cambrian boundary is securely located. Carbon isotopic data have been acquired, and at high resolution through the cap level, which is locally well preserved in south China. Ediacaran megafossils, however, are rare in the Chinese sections, and while a number of candidate Ediacara fossils have been published from India, at least some and perhaps most of these can be interpreted in other ways. Most promising in this regard may be structures assigned to Pteridinium by Shanker et al. (2004), but even these differ from Pteridinium described previously from other regions, and more specimens will be required to understand their origin. The proposed GSSP locations, in the vicinity of Yichang in China, and Dehradun, India, are relatively accessible by air and rail. The main shortcomings of these sections relate to the overall quality and continuity of exposure, particularly at the cap level. The rocks in the Lesser Himalaya are considerably more deformed than their counterparts in the Flinders Ranges. In neither area does the level of systematic geological mapping and availability of mapping match that in Australia. Marinoan glacial deposits beneath the level of the GSSP (the Nantuo Formation in China and the Blaini Formation in India) are not well documented, or recently studied.

The final candidate, the base of the Wearing Dolomite in the Flinders Ranges of Australia, is at an isotopic excursion below the first occurrence of Ediacara-type fossils in the section. This boundary is at a considerably higher stratigraphic level than was agreed to in the 1st Ballot. The relatively few occurrences of the Ediacara biota worldwide do not at present provide sufficient constraints to use the first appearance of Ediacaran fossils in a local section as a reliable biostratigraphic indicator, and the proposed boundary is difficult to categorize or correlate using other criteria. 